\title{
Role of physical and biological processes in sediment dynamics of a tidal flat in Westerschelde Estuary, SW Netherlands
}

\author{
J. Widdows ${ }^{1, *}$, A. Blauw ${ }^{2}$, C. H. R. Heip ${ }^{3}$, P. M. J. Herman ${ }^{3}$, C. H. Lucas ${ }^{4}$, \\ J. J. Middelburg ${ }^{3}$, S. Schmidt ${ }^{5}$, M. D. Brinsley ${ }^{1}$, F. Twisk ${ }^{6}{ }^{6}$ H. Verbeek $^{6}$ \\ ${ }^{1}$ Plymouth Marine Laboratory, Prospect Place, The Hoe, Plymouth PL1 3DH, UK \\ ${ }^{2}$ WL I Delft Hydraulics, PO Box 177, 2600 MH Delft, The Netherlands \\ ${ }^{3}$ Netherlands Institute of Ecology, Centre for Estuarine and Marine Ecology (NIOO-KNAW), Korringaweg 7, PO Box 140, \\ 4401 AC Yerseke, The Netherlands \\ ${ }^{4}$ School of Ocean and Earth Science, University of Southampton, Southampton Oceanography Centre, European Way, \\ Southampton SO14 3ZH, UK \\ ${ }^{5}$ Laboratoire des Sciences du Climat et de l'Environnement (CEA-CNRS), Domaine du CNRS, Avenue de la Terrasse, \\ 91198 Gif-sur-Yvette Cedex, France \\ ${ }^{6}$ National Institute for Coastal and Marine Management, Grenadresweg 31, PO Box 8039, 4330 EA Middelburg, The Netherlands
}

\begin{abstract}
This article synthesises a series of studies concerned with physical, chemical and biological processes involved in sediment dynamics (sedimentation, erosion and mixing) of the Molenplaat tidal flat in the Westerschelde (SW Netherlands). Total sediment accretion rate on the flat (sand to muddy sand) was estimated to be $\sim 2 \mathrm{~cm} \mathrm{yr}^{-1}$, based on ${ }^{210} \mathrm{~Pb}$ and ${ }^{137} \mathrm{Cs}$ profiles. ${ }^{7} \mathrm{Be}$ showed maximum activity in the surface sediments during summer, reflecting accretion of fine silt at this time of year, and total vertical mixing of sediment to be in the order of $50 \mathrm{~cm}^{2} \mathrm{yr}^{-1}$. The extent to which different physical and biological processes (tidal currents, air exposure, bio-stabilisation, biodeposition and bioturbation) contributed towards sediment dynamics was estimated. A sediment transport model based on physical factors estimated sedimentation rates of $1.2 \mathrm{~cm} \mathrm{yr}^{-1}$, but did not account for tidal or seasonal variation in suspended particulate matter (SPM), wind or effects of spring-neap tidal cycles. When the model was run with an increased critical bed shear stress due to the microphytobenthos, net sedimentation rates increased 2-fold. These higher rates were in closer agreement with the rates derived from the depth profiles of radionuclides for the central region of the tidal flat $\left(2.0\right.$ to $\left.2.4 \mathrm{~cm} \mathrm{yr}^{-1}\right)$. Therefore a significant part of the sedimentation rate $(\sim 50 \%)$ may be explained by spatial-temporal changes in biological processes, including 'bio-stabilisation' by microphytobenthos, together with the enhanced biodeposition of silt by suspension feeders, and offset by processes of 'bio-destabilisation' by grazers and bioturbators. In the centre of the tidal flat there was a shift from high sediment stability in spring-summer 1996 to low sediment stability in autumn 1997, quantified by a significant reduction in critical erosion velocity of 0.12 to $0.15 \mathrm{~m} \mathrm{~s}^{-1}$, and accompanied by a 30 - to 50 -fold increase in sediment erosion rate. The change was associated with a shift from a tidal flat dominated by benthic diatoms and a low biomass of bioturbating clams (Macoma balthica), to a more erodable sediment with a lower microphytobenthos density and a higher biomass of $M$. balthica. Vertical mixing of sediment and organic matter, studied using a variety of tracers, was rapid and enhanced by advective water flow at sandy sites and by burrowing polychaetes and bivalves at silty sites.
\end{abstract}

KEY WORDS: Sediment dynamics - Erosion · Sedimentation · Mixing • Microphytobenthos · Biostabilisation · Bioturbation · Modelling

Resale or republication not permitted without written consent of the publisher

\section{INTRODUCTION}

Tidal flats form important morphological structures in meso- and macro-tidal estuaries and coastal systems. During each tidal cycle they are exposed to air and can occupy over half the total area of an estuary. Sand and mudflats provide a range of valuable habitats which are highly productive areas for benthic organisms (Heip et al. 1995), thus providing important feeding grounds for fishes during high water and for birds during low water. 
The sediment dynamics and biogeochemistry of tidal flats is dependent on the complex interactions between physical, chemical and biological processes/properties, which include tidal currents, river flows, storm waves, air exposure, dehydration in summer, ice-scour in winter, sediment properties (grain size and composition, organic content, nutrient content, redox balance), stabilisation by biota (algal biofilms, mussel beds, salt marsh) and destabilisation by biota (bioturbating bivalves, scouring around clumps of animals and plants). To date, there have been very few multi-disciplinary studies providing an integrated view of the sediment dynamics of intertidal mudflats and sandflats. These include the Canadian LISP (littoral investigation of sediment properties; Daborn 1991), the UK LISP (Black et al. 1998, Black 1999), the EU INTRMUD (Dyer 2000) and the EU ECOFLAT (Herman et al. 2001) programmes. An important objective of the ECOFLAT project (eco-metabolism of an estuarine tidal flat) was to apply a multidisciplinary approach to investigate the many complex physical, chemical and biological interactions and to quantify, understand and model the dynamic behaviour of tidal flats as geomorphological and metabolic systems (overview by Herman et al. 2001).

During the EU ECOFLAT project various approaches were used to investigate the material fluxes and sediment dynamics of the Molenplaat tidal flat in the Westerschelde over different temporal and spatial scales. These included

- long-term sediment accretion (Schmidt et al. 1999);

- short-term (seasonal) variations in sedimentation rates (Schmidt et al. 1999);
- seasonal variations in sediment properties and benthic community structure (Herman et al. 1999);

- modelling of sediment dynamics (fine silt) as a function of tidal currents (Baptist et al. 1999);

- the impact of currents, macrobenthos and microphytobenthos on sediment erosion and deposition processes (Widdows et al. 2000a, Lucas et al. 2003);

- tidal variations in resuspension of microphytobenthos (Lucas et al. 2000, 2001);

- vertical mixing of sediment estimated by tracer experiments (Herman et al. 2000, Middelburg et al. 2000).

In this paper we present new data on sediment accretion and mixing, sediment characteristics (grain size, algal pigments, carbohydrates), sediment erodability, hydrodynamics, sediment community respiration, organic carbon and nutrient burial, and simulations with a sediment transport model. These new findings are combined with the results mentioned above to present a synthesis and more integrated view of erosion, sedimentation, and mixing processes occurring on a tidal flat, and the nature of interactions between physical-biological processes in sediment dynamics.

\section{MATERIALS AND METHODS}

Site description. The Molenplaat tidal flat (Fig. 1) is located in the middle part of the Westerschelde (SW Netherlands). This is a macrotidal estuary with a tidal range of ca. $5 \mathrm{~m}$, and at the Molenplaat site, salinity

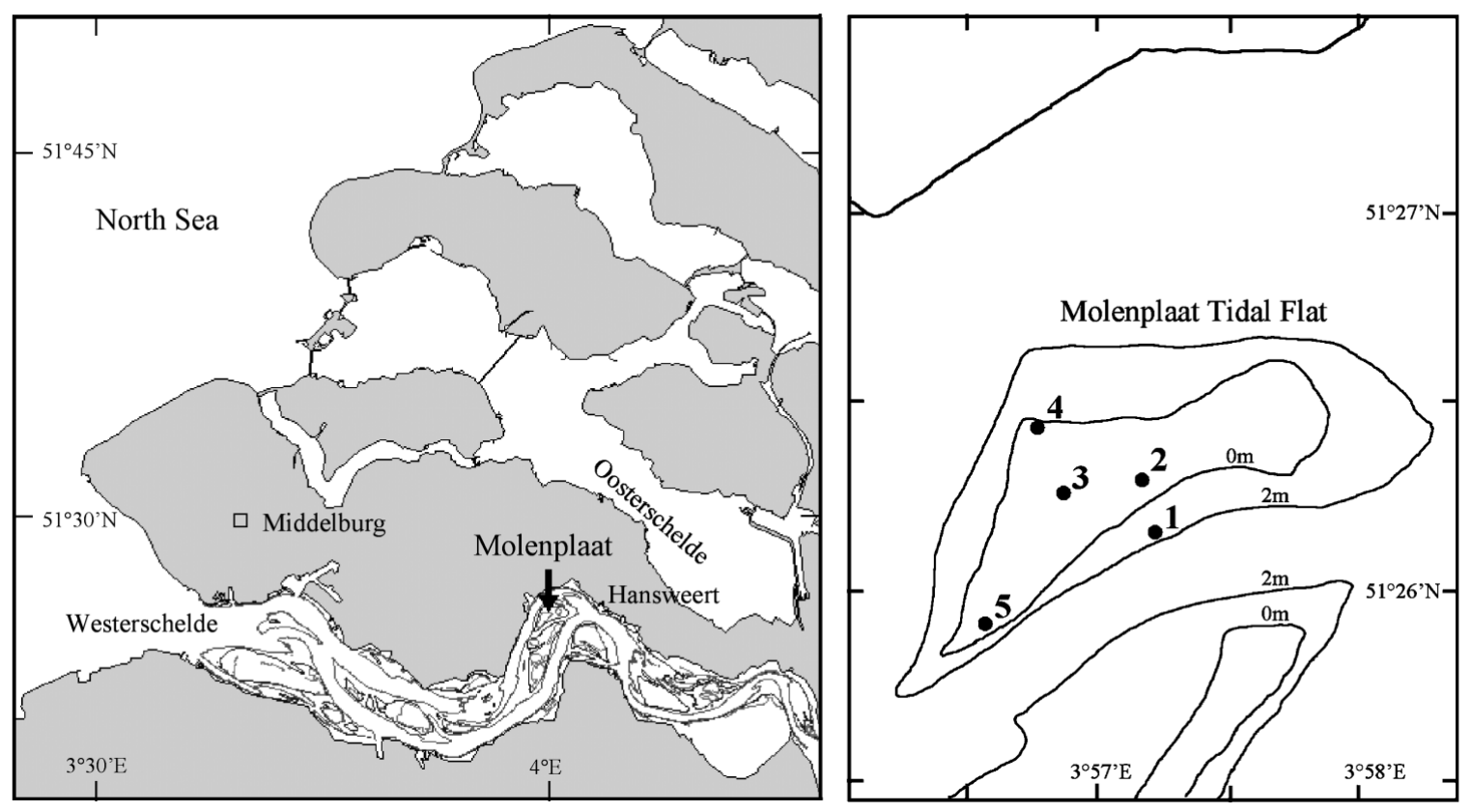

Fig. 1. Location of Molenplaat tidal flat and 5 sampling sites. Isolines represent low-tide level (2 m) and mid-tide level (0 m) 
varies between 20 and 25. We studied 5 sites (Fig. 1) during 4 ECOFLAT field campaigns in the spring (May/June) and late summer (August/September) of 1996 and 1997. The main physical and biogeochemical characteristics of the Molenplaat sites are summarised in Table 1.

Measurement of long-term and short-term sediment accumulation rates. Deep cores (40 to $120 \mathrm{~cm}$ ) were collected at low tide using a hand-driven tube (1.2 $\mathrm{m}$ length and $0.1 \mathrm{~m}$ diameter) in June and September 1996 and 1997 at the 5 selected sites on the Molenplaat. Cores for radionuclide activity deter- minations were sliced at a resolution of 1 to $2 \mathrm{~cm}$ after upward extrusion of the cores, and were dried at $60^{\circ} \mathrm{C}$. Activities of the radionuclides ${ }^{137} \mathrm{Cs},{ }^{210} \mathrm{~Pb}$ and ${ }^{226} \mathrm{Ra}$ were measured directly by low-backgroundhigh efficiency $\gamma$ spectrometry (for details of sampling, processing and radioisotope analysis see Schmidt et al. 1999).

The central site, Site 2, had the highest levels of radionuclides and was therefore used for the seasonal study of sedimentation of fine silt. We collected 5 cores, 1 on each sampling occasion during June 1996, September 1996, March 1997, June 1997 and September

Table 1. Main physical, chemical and biological characteristics of sampling sites on Molenplaat tidal flat in Westerschelde. $U_{\text {crit }}$ : critical erosion velocity for bed sediments (suspended particulate matter threshold of $100 \mathrm{mg} \mathrm{l}^{-1}$ ). Data are means, with SE in italics; semi-range in parentheses; -: no replication; nd: not determined

\begin{tabular}{|c|c|c|c|c|c|c|c|c|c|c|c|}
\hline \multirow[t]{2}{*}{ Parameter } & \multirow[t]{2}{*}{ Year } & \multicolumn{2}{|c|}{ Site 1} & \multicolumn{2}{|c|}{ Site 2} & \multicolumn{2}{|c|}{ Site 3} & \multicolumn{2}{|c|}{ Site 4} & \multicolumn{2}{|c|}{ Site 5} \\
\hline & & Jun & Sep & Jun & Sep & Jun & Sep & Jun & Sep & Jun & Sep \\
\hline \multicolumn{2}{|l|}{ Emersion period per tidal cycle (h) } & \multicolumn{2}{|c|}{4.5} & \multicolumn{2}{|c|}{7} & \multicolumn{2}{|c|}{7} & \multicolumn{2}{|c|}{6.5} & \multicolumn{2}{|c|}{7.5} \\
\hline \multicolumn{2}{|l|}{$\begin{array}{l}\text { Min. and max. current velocities }\left(\mathrm{m} \mathrm{s}^{-1}\right) \\
10 \mathrm{~cm} \text { above bed for spring tides }\end{array}$} & \multicolumn{2}{|c|}{$0.06-0.38$} & \multicolumn{2}{|c|}{$0.04-0.36$} & \multicolumn{2}{|c|}{$0.02-0.36$} & \multicolumn{2}{|c|}{$0.04-0.40$} & \multicolumn{2}{|c|}{$0.05-0.35$} \\
\hline \multirow[t]{2}{*}{$\begin{array}{l}\text { Sediment grain size } \\
(\% \text { sand }>63 \mu \mathrm{m})\end{array}$} & 1996 & $\begin{array}{l}87 \\
0.8\end{array}$ & $\begin{array}{l}91 \\
0.4\end{array}$ & $\begin{array}{l}68 \\
2.5\end{array}$ & $\begin{array}{l}61 \\
2.3\end{array}$ & $\begin{array}{l}85 \\
0.4\end{array}$ & $\begin{array}{c}89 \\
0.55\end{array}$ & nd & nd & $\begin{array}{c}99 \\
(0.0)\end{array}$ & $\begin{array}{l}99 \\
0.2\end{array}$ \\
\hline & 1997 & $\begin{array}{l}88 \\
0.3\end{array}$ & $\begin{array}{l}88 \\
0.6\end{array}$ & $\begin{array}{l}75 \\
0.5\end{array}$ & $\begin{array}{l}59 \\
2.9\end{array}$ & $\begin{array}{l}94 \\
0.1\end{array}$ & nd & $\begin{array}{l}99 \\
0.1\end{array}$ & $\begin{array}{l}99 \\
0.0\end{array}$ & $\begin{array}{c}99 \\
(0.0)\end{array}$ & nd \\
\hline \multirow[t]{2}{*}{$\begin{array}{l}\% \text { ash-free dry wt in sediment } \\
\text { (0 to } 2 \mathrm{~cm} \text { depth) }\end{array}$} & 1996 & $\begin{array}{l}1.2 \\
0.0\end{array}$ & $\begin{array}{l}1.0 \\
0.0\end{array}$ & $\begin{array}{l}1.6 \\
0.1\end{array}$ & $\begin{array}{l}3.1 \\
0.1\end{array}$ & $\begin{array}{l}1.2 \\
0.0\end{array}$ & $\begin{array}{l}1.3 \\
0.0\end{array}$ & nd & nd & $\begin{array}{l}0.5 \\
0.0\end{array}$ & $\begin{array}{l}0.6 \\
0.0\end{array}$ \\
\hline & 1997 & $\begin{array}{l}1.2 \\
0.1\end{array}$ & $\begin{array}{l}1.3 \\
0.0\end{array}$ & $\begin{array}{l}1.7 \\
0.0\end{array}$ & $\begin{array}{l}3.1 \\
0.1\end{array}$ & $\begin{array}{l}0.9 \\
0.0\end{array}$ & nd & $\begin{array}{l}0.5 \\
0.0\end{array}$ & $\begin{array}{l}0.6 \\
0.0\end{array}$ & $\begin{array}{l}0.4 \\
0.0\end{array}$ & nd \\
\hline \multirow[t]{2}{*}{$\begin{array}{l}\text { Chlorophyll a } \\
\text { ( } \mu \mathrm{g} \mathrm{g}^{-1} \text { dry wt at } 0 \text { to } 2 \mathrm{~mm} \text { depth) }\end{array}$} & 1996 & $\begin{array}{c}35.5 \\
\pm 2.4\end{array}$ & $\begin{array}{c}2.0 \\
\pm 0.1\end{array}$ & $\begin{array}{c}35.6 \\
\pm 2.3\end{array}$ & $\begin{array}{c}5.4 \\
\pm 0.4\end{array}$ & $\begin{array}{c}26.1 \\
\pm 2.8\end{array}$ & $\begin{array}{c}2.6 \\
\pm 0.5\end{array}$ & $\begin{array}{c}2.4 \\
\pm 0.4\end{array}$ & $\begin{array}{c}1.9 \\
\pm 0.1\end{array}$ & $\begin{array}{c}1.2 \\
\pm 0.2\end{array}$ & $\begin{array}{c}0.8 \\
\pm 0.1\end{array}$ \\
\hline & 1997 & $\begin{array}{c}12.6 \\
\pm 1.2\end{array}$ & $\begin{array}{c}4.9 \\
\pm 0.7\end{array}$ & $\begin{array}{c}64.0 \\
\pm 10.5\end{array}$ & $\begin{array}{c}6.8 \\
\pm 0.8\end{array}$ & $\begin{array}{c}10.6 \\
\pm 1.7\end{array}$ & $\begin{array}{c}5.7 \\
\pm 0.4\end{array}$ & $\begin{array}{c}7.1 \\
\pm 1.2\end{array}$ & $\begin{array}{c}1.8 \\
\pm 0.2\end{array}$ & $\begin{array}{c}1.3 \\
\pm 0.2\end{array}$ & $\begin{array}{l}0.75 \\
\pm 0.2\end{array}$ \\
\hline \multirow[t]{2}{*}{$\begin{array}{l}\text { Colloidal carbohydrates ( } \mu \mathrm{g} \text { gluc. } \\
\text { equiv. } \mathrm{g}^{-1} \text { dry wt at } 0 \text { to } 2 \mathrm{~mm} \text { depth) }\end{array}$} & 1996 & $\begin{array}{c}131 \\
\pm 19\end{array}$ & $\begin{array}{c}17 \\
\pm 6\end{array}$ & $\begin{array}{l}352 \\
\pm 60\end{array}$ & $\begin{array}{l}31 \\
\pm 5\end{array}$ & $\begin{array}{l}102 \\
\pm 9\end{array}$ & $\begin{array}{l}39 \\
\pm 6\end{array}$ & $\begin{array}{c}11 \\
\pm 1\end{array}$ & $\begin{array}{c}4 \\
\pm 0.5\end{array}$ & $\begin{array}{c}7 \\
\pm 1\end{array}$ & $\begin{array}{c}7 \\
\pm 2\end{array}$ \\
\hline & 1997 & $\begin{array}{l}43 \\
\pm 5\end{array}$ & $\begin{array}{c}35 \\
\pm 5\end{array}$ & $\begin{array}{c}356 \\
\pm 66\end{array}$ & $\begin{array}{c}56 \\
\pm 11\end{array}$ & $\begin{array}{c}86 \\
\pm 18\end{array}$ & $\begin{array}{c}45 \\
\pm 15\end{array}$ & $\begin{array}{c}50 \\
\pm 16\end{array}$ & $\begin{array}{c}33 \\
\pm 10\end{array}$ & $\begin{array}{c}5 \\
\pm 1\end{array}$ & nd \\
\hline \multirow[t]{2}{*}{ Macoma balthica biomass $\left(\mathrm{g} \mathrm{m}^{-2}\right)$} & 1996 & $\begin{array}{l}10.3 \\
(1.6)\end{array}$ & $\begin{array}{l}14.0 \\
(1.6)\end{array}$ & $\begin{array}{c}4.6 \\
(0.4)\end{array}$ & $\begin{array}{c}2.1 \\
(0.5)\end{array}$ & $\begin{array}{c}7.1 \\
(0.7)\end{array}$ & $\begin{array}{c}7.1 \\
(0.1)\end{array}$ & nd & nd & $\begin{array}{c}0 \\
(0)\end{array}$ & $\begin{array}{c}0 \\
(O)\end{array}$ \\
\hline & 1997 & $\begin{array}{c}9.1 \\
(3.1)\end{array}$ & $\begin{array}{c}4.6 \\
(0.3)\end{array}$ & $\begin{array}{l}26.3 \\
(3.8)\end{array}$ & $\begin{array}{l}18.4 \\
(7.8)\end{array}$ & $\begin{array}{l}36.9 \\
(8.6)\end{array}$ & nd & $\begin{array}{l}16.6 \\
(0.1)\end{array}$ & $\begin{array}{c}7.8 \\
(0.2)\end{array}$ & nd & nd \\
\hline \multirow[t]{2}{*}{ Cerastoderma edule biomass $\left(\mathrm{g} \mathrm{m}^{-2}\right)$} & 1996 & $\begin{array}{c}4.7 \\
(2.8)\end{array}$ & $\begin{array}{c}0 \\
(0)\end{array}$ & $\begin{array}{c}4.9 \\
(0.1)\end{array}$ & $\begin{array}{c}2.0 \\
(1.0)\end{array}$ & $\begin{array}{c}3.3 \\
(0.1)\end{array}$ & $\begin{array}{c}3.9 \\
(0.4)\end{array}$ & nd & nd & $\begin{array}{c}0 \\
(0)\end{array}$ & $\begin{array}{c}0 \\
(0)\end{array}$ \\
\hline & 1997 & $\begin{array}{c}0.2 \\
(0.2)\end{array}$ & $\begin{array}{c}0.02 \\
(0.02)\end{array}$ & $\begin{array}{c}0 \\
(0)\end{array}$ & $\begin{array}{l}27.5 \\
(8.5)\end{array}$ & $\begin{array}{c}7.4 \\
(7.3)\end{array}$ & $\begin{array}{l}\text { nd } \\
(1.0)\end{array}$ & $\begin{array}{c}1.0 \\
(0.18)\end{array}$ & 6.8 & nd & nd \\
\hline \multirow[t]{2}{*}{$U_{\text {crit }}\left(\mathrm{m} \mathrm{s}^{-1}\right)$} & 1996 & $\begin{array}{c}0.30 \\
(0.01)\end{array}$ & $\begin{array}{c}0.14 \\
(0.01)\end{array}$ & $\begin{array}{c}0.31 \\
-\end{array}$ & $\begin{array}{c}0.18 \\
(0.01)\end{array}$ & $\begin{array}{c}0.37 \\
-\end{array}$ & $\begin{array}{c}0.21 \\
(0)\end{array}$ & nd & nd & $\begin{array}{c}0.31 \\
-\end{array}$ & $\begin{array}{c}0.16 \\
(0.01)\end{array}$ \\
\hline & 1997 & $\begin{array}{c}0.20 \\
(0.02)\end{array}$ & $\begin{array}{c}0.18 \\
(0)\end{array}$ & $\begin{array}{c}0.25 \\
(0)\end{array}$ & $\begin{array}{c}0.18 \\
(0)\end{array}$ & $\begin{array}{c}0.22 \\
(0)\end{array}$ & nd & $\begin{array}{c}0.23 \\
(0.01)\end{array}$ & $\begin{array}{c}0.19 \\
(0.01)\end{array}$ & nd & nd \\
\hline \multirow[t]{2}{*}{ Mass eroded $\left(\mathrm{g} \mathrm{m}^{-2}\right)$ at $0.3 \mathrm{~m} \mathrm{~s}^{-1}$} & 1996 & $\begin{array}{l}65 \\
(11)\end{array}$ & $\begin{array}{c}2068 \\
(99)\end{array}$ & $\begin{array}{l}29 \\
-\end{array}$ & $\begin{array}{l}390 \\
(74)\end{array}$ & $\begin{array}{c}6.8 \\
-\end{array}$ & $\begin{array}{l}457 \\
(91)\end{array}$ & nd & nd & $\begin{array}{c}39.5 \\
-\end{array}$ & $\begin{array}{c}943 \\
(154)\end{array}$ \\
\hline & 1997 & $\begin{array}{l}1150 \\
(565)\end{array}$ & $\begin{array}{c}2252 \\
(7)\end{array}$ & $\begin{array}{l}126 \\
(19)\end{array}$ & $\begin{array}{l}785 \\
(57)\end{array}$ & $\begin{array}{l}1180 \\
(195)\end{array}$ & nd & $\begin{array}{l}350 \\
(36)\end{array}$ & $\begin{array}{l}823 \\
(88)\end{array}$ & nd & nd \\
\hline \multirow[t]{2}{*}{$\begin{array}{l}\text { Max. erosion rate } \\
\left(\mathrm{g} \mathrm{m}^{-2} \mathrm{~s}^{-1}\right) \text { at } 0.3 \mathrm{~m} \mathrm{~s}^{-1}\end{array}$} & 1996 & $\begin{array}{c}0.28 \\
(0.05)\end{array}$ & $\begin{array}{l}6.02 \\
(0.3)\end{array}$ & $\begin{array}{c}0.10 \\
-\end{array}$ & $\begin{array}{l}1.67 \\
(0.4)\end{array}$ & $\begin{array}{c}0.05 \\
-\end{array}$ & $\begin{array}{l}2.15 \\
(0.14)\end{array}$ & nd & nd & $\begin{array}{c}0.43 \\
-\end{array}$ & $\begin{array}{c}7.49 \\
-\end{array}$ \\
\hline & 1997 & $\begin{array}{c}2.48 \\
(1.06)\end{array}$ & $\begin{array}{l}4.38 \\
0.57\end{array}$ & $\begin{array}{c}0.53 \\
(0.01)\end{array}$ & $\begin{array}{l}3.04 \\
0.20\end{array}$ & $\begin{array}{c}2.41 \\
(0.43)\end{array}$ & nd & $\begin{array}{c}1.9 \\
(0.37)\end{array}$ & $\begin{array}{c}4.1 \\
(0.59)\end{array}$ & nd & nd \\
\hline
\end{tabular}


1997. Activity of ${ }^{7} \mathrm{Be}$ in the top $6 \mathrm{~cm}$ of the sediment was used to determine short-term seasonal changes in sedimentation (for details of the methodology see Schmidt et al. 1999).

The number of samples was restricted by the timeconsuming coring process during low tide and the limited time available for counting samples for ${ }^{7} \mathrm{Be}$ activity, characterised by a short half-life and low levels. While the lack of sample replication limits the interpretation of spatial and temporal variation, the good agreement in vertical profiles for 1996 and 1997 enables sedimentation rates to be estimated with confidence.

Measurement of carbon dynamics. Single cores (0.1 m diameter) were taken during the June 1997 campaign at the 5 Molenplaat sites to a depth of $0.5 \mathrm{~m}$ and sliced in $2 \mathrm{~cm}$ slices. For each slice, water content was calculated from weight loss, and porosity was calculated from water content, assuming a dry sediment density of $2650 \mathrm{~kg} \mathrm{~m}^{-3}$. Total nitrogen and organic carbon were determined with a Carlo Erba NA 1500 elemental analyzer, after in situ hydrochloric acid $(25 \%)$ acidification to remove the inorganic carbon (Nieuwenhuize et al. 1994). Carbon and nitrogen content and porosity were averaged over the 5 slices between 0.4 and $0.5 \mathrm{~m}$ depth, and multiplied by sediment accumulation rate, dry density and solid volume fraction to determine burial rates.

Organic matter mineralisation rates are based on the efflux of carbon dioxide. During the September 1997 campaign at the 5 Molenplaat sites, carbon dioxide fluxes were measured using non-transparent polypropylene flux chambers and a photo-acoustic infra-red analyser for measurement of the accumulation of carbon dioxide (Middelburg et al. 1996). Carbonate dissolution may potentially affect mineralisation rates based on total inorganic fluxes. However, we used low-tide carbon dioxide gas fluxes and not total inorganic carbon fluxes during submerged conditions. Middelburg et al. (1996) have shown that gaseous carbon dioxide fluxes agree within error with sulphate reduction rates based on ${ }^{35} \mathrm{~S}$ incubations. This allows little error to be attributed to carbonate dissolution.

Measurment of fate of microphytobenthos using stable isotopes as physical and trophic tracers. The relative importance of microphytobenthos as food for intertidal macrobenthic animals and the fate of labelled organic matter in the sediment was studied at 2 locations on the Molenplaat tidal flat (Sites 2 and 4) using the stable isotope ${ }^{13} \mathrm{C}$ as a tracer (for details see Middelburg et al. 2000). We used 2 different approaches: (1) the natural abundance of stable isotope ratios of carbon and nitrogen in the biota at Sites 2 and 4 ; and (2) an in situ addition of ${ }^{13} \mathrm{C}$-bicarbonate to the surficial sediments at Sites 2 and 4 and its subsequent incorporation into the benthic food web (Herman et al. 2000, Middelburg et al. 2000).

Measurement of sediment properties and erodability. Spatial and temporal changes in the main physical, chemical and biological properties of the sediment on the Molenplaat were measured according to standardised procedures. Sediment grain size was analysed by wet-sieving (Widdows et al. 2000a). Cores $(2.54 \mathrm{~cm}$ diameter; $\mathrm{n}=4$ or 6 ) for algal pigment determinations were collected randomly over $1 \mathrm{~m}^{2}$ and were sliced for the superficial 0 to $2 \mathrm{~mm}$ layer and at 2 to 4,4 to 6 , 6 to 10,10 to 15 and 15 to $20 \mathrm{~mm}$ depth intervals. Plant pigments were extracted with $90 \%$ acetone and the pigments were separated and quantified using ion-pairing reverse-phase high-performance liquid chromatography (HLPC) (Barlow et al. 1993, Lucas \& Holligan 1999, Lucas et al. 2000). Colloidal carbohydrates were quantified by the phenol-sulphuric method (Underwood et al. 1995).

The Plymouth Marine Laboratory annular flumes were used to quantify benthic-pelagic exchanges in relation to important physical and biological factors (i.e. current velocity, sediment properties and benthic biota). The flume has a $0.64 \mathrm{~m}$ outer and $0.44 \mathrm{~m}$ inner diameter, creating a $0.1 \mathrm{~m}$ annular channel. It has a total bed area of $0.17 \mathrm{~m}^{2}$ and a volume of $60 \mathrm{l}$. Freestream current velocities, ranging from 0.01 to $0.50 \mathrm{~m}$ $\mathrm{s}^{-1}$, are created by a rotating annular drive plate (without paddles) situated $0.20 \mathrm{~m}$ above the sediment. Changes in suspended sediment concentration are monitored with an optical backscatter sensor (OBS-3; D \& A Instruments) calibrated against water samples taken for gravimetric analysis. The relationship between depth-averaged current velocity $\left(U_{i} \mathrm{~cm} \mathrm{~s}^{-1}\right)$ and bed shear stress for smooth cohesive mud, measured using a Sontek acoustic Doppler velocimeter, is described by the following equation:

Bed shear stress $(\mathrm{Pa})=1 \mathrm{E}-05 U^{3}-0.0002 U^{2}+0.0052 U$

Sediment erodability was quantified in terms of critical erosion velocity $\left(U_{\text {crit }}\right)$, mass of sediment eroded $\left(\mathrm{g} \mathrm{m}^{-2}\right)$ and erosion rate $\left(\mathrm{g} \mathrm{m}^{-2} \mathrm{~s}^{-1}\right)$. The enhancement of sedimentation by suspension-feeders was measured in terms of biodeposition rates (faeces and pseudofaeces production; $\mathrm{g} \mathrm{m}^{-2} \mathrm{~h}^{-1}$ ) (for further details of flume-based flux measurements see Widdows et al. 1998a, 2000a). Flume-based measurements made on the Molenplaat in June and September 1997 represent new data to complement the 1996 data previously published by Widdows et al. (2000a).

The relationships between physical, chemical and biological sediment properties were analysed using the Pearson product-moment correlation coefficient (Minitab 13). 
Modelling of hydrodynamics and sediment dynamics. A 2D hydrodynamic model of the water levels and currents over the Molenplaat tidal flat was developed with a spatial resolution of 10 s of metres. Maximum bottom shear stresses ranged from $0.3 \mathrm{~Pa}$ for the central region to $3 \mathrm{~Pa}$ for the western edge of the Molenplaat. The resulting water levels and current patterns were then used to drive the sediment transport model of erosion/sedimentation on the tidal flat (for details see Baptist et al. 1999).

Sediment transport modelling. A sediment model coupled to a 2D hydrodynamics model has been developed for the Molenplaat tidal flat (Baptist et al. 1999). The initial parameterisation of the sediment transport model relies only on physical factors (i.e. no biotic influences) to simulate the transport of suspended particulate matter and the sedimentation and erosion patterns. The model uses 1 sediment fraction (silt) and is based on a hydrodynamic model of the Molenplaat for June 1995. Sedimentation processes are modelled with formulations according to Krone (1962) and resuspension processes according to Parthenaides (1962). The variables in the model are the concentration of fine silt in the water $\left(\mathrm{g} \mathrm{m}^{-3}\right)$ and fine silt in the sediment $\left(\mathrm{g} \mathrm{m}^{-2}\right)$.

The sediment model was calibrated using 2 data sets that were obtained by monitoring on the Molenplaat in June 1995 and 1996. Temporal sediment dynamics was calibrated to time series of suspended sediment during several tides at 2 monitoring locations. Spatial sedimentation and erosion patterns were calibrated to the distribution of fine silt ( $\%$ of total sediment) on the Molenplaat.

Using this calibrated model, the net sedimentation flux was estimated for the central part of the Molenplaat. An initial silt distribution on the bottom was estimated by a preceding $20 \mathrm{~d}$ simulation, starting with a uniform layer of $1 \mathrm{~cm}$ silt in the whole model area.

For comparison, the same model was run with a spatially varying, critical bed shear stress, depending on microphytobenthos density. The measurements of chlorophyll $a$ in the sediment have been converted into an interpolated field of critical bed shear stress using the relation found in flume studies (Widdows et al. 1998, 2000a):

$$
U_{\text {crit }}=0.4049 \times \mathrm{chl}+15.064
$$

where $U_{\text {crit }}=\mathrm{cm} \mathrm{s}^{-1}$ and $\mathrm{chl}=$ chlorophyll $\mathrm{a}$ in sediment ( $\mu \mathrm{g} \mathrm{g}^{-1}$ dry wt).

This formula can be transformed into:

$$
\tau_{\text {crit }}=0.0142 \times \mathrm{chl}+0.1697
$$

As a consequence the sediment stability increases in areas with high microphytobenthos density and decreases in areas without microphytobenthos biofilms.

\section{RESULTS AND DISCUSSION}

\section{Long-term sediment accumulation rates}

Direct measurement of sedimentation rates on tidal flats is extremely difficult. However, an indirect method involves the use of natural and artificial radionuclides with known decay rates. ${ }^{210} \mathrm{~Pb}$ is a naturally occurring radionuclide of the ${ }^{238} \mathrm{U}$ decay series. The ${ }^{210} \mathrm{~Pb}$ method (with a half-life of $t_{1 / 2}=22.3 \mathrm{yr}$ ) is based on the measurement of the excess, or unsupported ${ }^{210} \mathrm{~Pb}$ activity, which is incorporated into accumulating sediment from atmospheric fallout. In contrast, the main source of ${ }^{137} \mathrm{Cs}\left(t_{1 / 2}=30 \mathrm{yr}\right)$ is fallout from the atmospheric testing of nuclear weapons. This technique allows the peak in ${ }^{137} \mathrm{Cs}$ activity within a core to be dated, as it records the 1963 fallout maximum. Sediment cores may also record the Chernobyl accident, which occurred on 26 April 1986 (Callaway et al. 1996).

The general feature of the Molenplaat is the low activity of the selected radionuclides in the sediments, particularly in comparison to previous tidal flat studies (Cundy \& Croudace 1995), due to the lower silt content (sediment grain size $<63 \mu \mathrm{m}$; Table 1). For all the sites, ${ }^{210} \mathrm{~Pb}_{\mathrm{xs}}$ (excess) showed weak activities at the surface, especially at Sites 4 and 5. Consequently, the decrease in ${ }^{210} \mathrm{~Pb}_{\mathrm{xs}}$ with increasing depth was not well-defined and sedimentation rates derived from ${ }^{210} \mathrm{~Pb}$ are used only to support ${ }^{137} \mathrm{Cs}$ results. Andersen et al. (2000) also encountered complications with the dating of intertidal mudflat sediments due to low activities, erosion-deposition events and mixing. The ${ }^{137} \mathrm{Cs}$ peak should correspond to a specific input of Cs from either atmospheric weapon tests or the Chernobyl event. A difference between both inputs is the occurrence of ${ }^{134} \mathrm{Cs}$ associated with the Chernobyl event; the ${ }^{134} \mathrm{Cs}$ resulting from weapon-testing, with a half-life period of $2 \mathrm{yr}$, has now completely disappeared after more than $30 \mathrm{yr}$. The absence of ${ }^{134} \mathrm{Cs}$ allows the deep peak to be attributed to the introduction of $\mathrm{Cs}$ by the weapon-testing programmes in the early sixties. This is confirmed by the rapid disappearance of $\mathrm{Cs}$ in the deepest part of cores. Profiles of ${ }^{137} \mathrm{Cs}$ were relatively constant on the Molenplaat, with the presence of a peak in activity at a depth of between 40 to $85 \mathrm{~cm}$, depending upon the site (Fig. 2). There was a consistency in the data for June 1996 and September 1997 (Sites 1 to 4), but the profile does not show a distinct peak for the very mobile sandy site, Site 5.

Sedimentation rates $\left(\mathrm{cm} \mathrm{yr}^{-1}\right)$ are presented in Table 2. Although the very low level of excess ${ }^{210} \mathrm{~Pb}$ limits the use of this method, profiles of ${ }^{210} \mathrm{~Pb}_{\mathrm{xs}}$ with depth strengthen mean rates derived from ${ }^{137} \mathrm{Cs}$ data. Sedimentation rates varied from $1.1 \mathrm{~cm} \mathrm{yr}^{-1}$ at the sandy exposed site on the edge of the Molenplaat tidal 


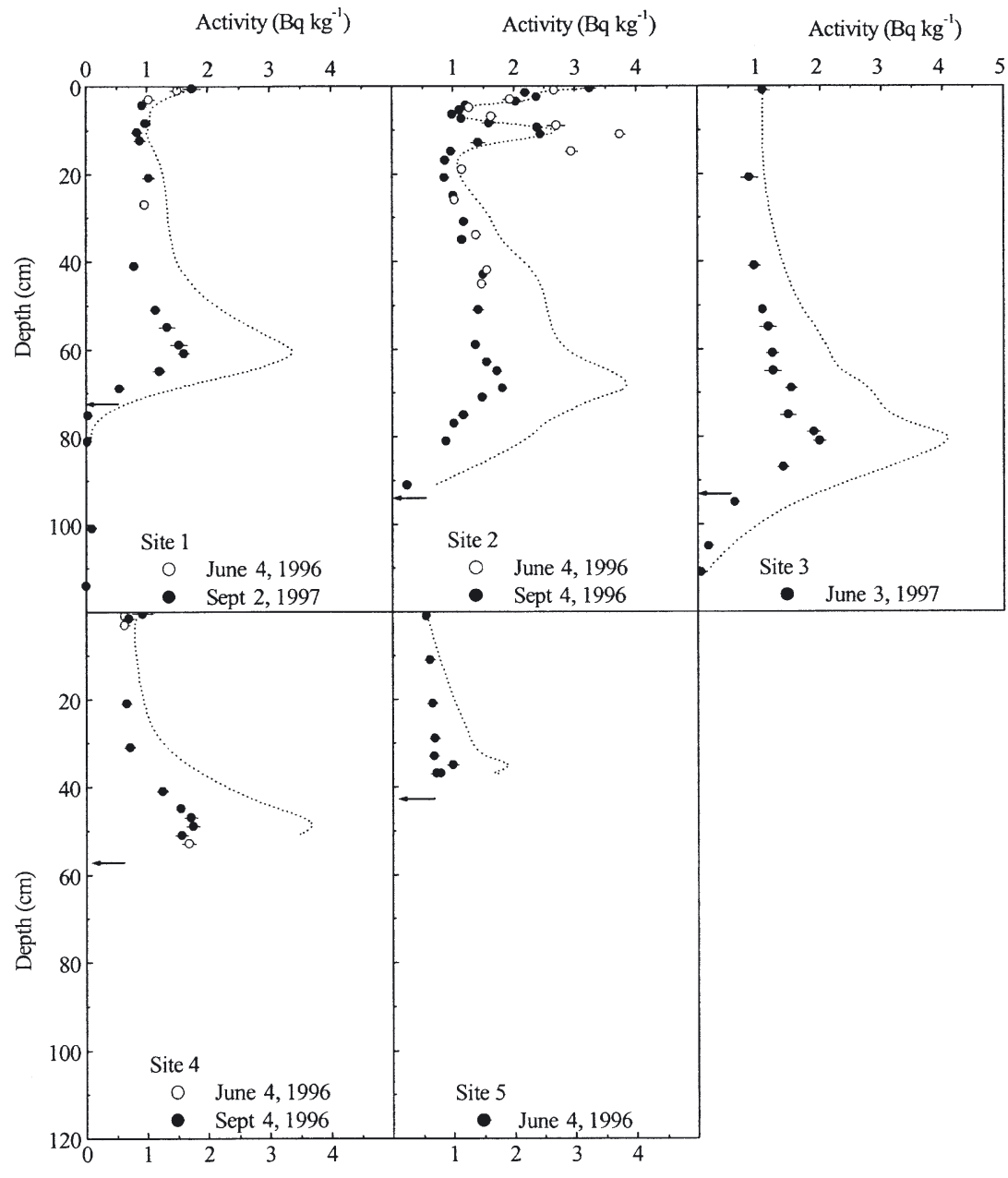

Fig. 2. Profiles of ${ }^{137} \mathrm{Cs}$ with depth. Arrows on profiles indicate predicted penetration depth of ${ }^{137} \mathrm{Cs}$ (sedimentation rate $\times 36 \mathrm{yr}$ since maximum input of ${ }^{137} \mathrm{Cs}$ into atmosphere). Dotted lines: ${ }^{137} \mathrm{Cs}$ activity corrected for decay rates due to compaction, tectonics and isostasy (P. Friend unpubl. data). This approach provided an average depositional rate for the whole Molenplaat tidal flat of $1.3 \pm$ $0.1 \mathrm{~cm} \mathrm{yr}^{-1}$ over the last $65 \mathrm{yr}$.

The organic carbon and nitrogen content of the 40 to $50 \mathrm{~cm}$ layer of sediment cores at the 5 sites on the Molenplaat are given in Table 2. The central sites, Sites 2 and 3, had the highest organic content in this deep layer of the cores. Site 1 was intermediate; values were lowest at the sandy sites, Sites 4 and 5. Using the ${ }^{137} \mathrm{Cs}$-based estimates of sediment accumulation rate at the different sites, this resulted in estimates of carbon burial ranging between $10 \mathrm{~g} \mathrm{C} \mathrm{m}^{-2}$ $\mathrm{yr}^{-1}$ at Site 5 and $105 \mathrm{~g} \mathrm{C} \mathrm{m}^{-2} \mathrm{yr}^{-1}$ at Site 3. A similar range of organic carbon burial rates (20 to $290 \mathrm{~g} \mathrm{C} \mathrm{m}^{-2} \mathrm{yr}^{-1}$ ) has been recorded in the Saguenay Fjord, Quebec (St-Onge \& Hillaire-Marcel 2001). Nitrogen burial was stoichiometrically related to carbon burial, with relatively high molar $\mathrm{C} / \mathrm{N}$ ratios of around 17, except at Site 5 where it was around 8. Organic matter mineralisation rates varied from $24 \mathrm{~g} \mathrm{C} \mathrm{m}^{-2}$ $\mathrm{yr}^{-1}$ at Site 5 to $226 \mathrm{gC} \mathrm{m}^{-2} \mathrm{yr}^{-1}$ at Site 2 (Table 2). The sandy sites, Sites 4 and 5, showed more variability than the more silty central sites (Sites 2 and 3).

Due to the high sediment accumulation rates, the rates of organic carbon and nitrogen burial were significant for the sediment and estuarine budgets of these constituents. The rates of organic carbon burial (10 to $105 \mathrm{~g} \mathrm{C} \mathrm{m}^{-2} \mathrm{yr}^{-1}$ ) were of similar magnitude to rates of sediment community respiration (24 to $226 \mathrm{~g} \mathrm{C} \mathrm{m}^{-2} \mathrm{yr}^{-1}$ ). Although the comparison of long-term carbon burial rates with short-term mineralisation rates contains uncertainties, it appears that about 30 to $40 \%$ of the total annual organic carbon input into the sediment at these stations is permanently buried (Table 2). The percentage burial found flat to $2.4 \mathrm{~cm} \mathrm{yr}^{-1}$ at the central site. These spatial differences in sedimentation rate are consistent with the variation in hydrodynamics, sediment properties and biological activity (see following subsections). In general, these values are in good agreement with an independent estimate of sedimentation rate on the flat, based on volume differences, corrected for subsidence

Table 2. Sediment accumulation rates, carbon and nitrogen contents, burial rates, mineralisation rates and burial efficiencies at the Molenplaat intertidal stations. Contents are given as mean values \pm standard deviation for the five $2 \mathrm{~cm}$ slices between 40 and $50 \mathrm{~cm}$ deep. Mineralisation rates are given as mean values \pm standard deviation for at least triplicate flux measurements

\begin{tabular}{|ccccccccc|}
\hline Site & $\begin{array}{c}\text { Sed. rate }\left(\mathrm{cm} \mathrm{yr}^{-1}\right) \text { based on } \\
{ }^{137} \mathrm{Cs}\end{array}$ & $\begin{array}{c}\text { Organic } \mathrm{C} \\
(\% \text { dry wt })\end{array}$ & $\begin{array}{c}\text { Total N } \\
(\% \text { dry wt })\end{array}$ & $\begin{array}{c}\text { Porosity } \\
-\end{array}$ & $\begin{array}{c}\mathrm{C} \text { burial } \\
\left(\mathrm{g} \mathrm{C} \mathrm{m}^{-2} \mathrm{yr}^{-1}\right)\end{array}$ & $\begin{array}{c}\mathrm{N} \text { burial } \\
\left(\mathrm{g} \mathrm{N} \mathrm{m}^{-2} \mathrm{yr}^{-1}\right)\end{array}$ & $\begin{array}{c}\mathrm{C} \text { mineral. } \\
\left(\mathrm{g} \mathrm{C} \mathrm{m}^{-2} \mathrm{yr}^{-1}\right)\end{array}$ & $\begin{array}{c}\mathrm{C} \text { burial } \\
\left.\mathrm{eff}^{(\%)}\right)\end{array}$ \\
\hline 1 & $1.8 \pm 0.1$ & 2.0 & $0.15 \pm 0.04$ & $0.010 \pm 0.001$ & 0.38 & 42 & 2.8 & $79 \pm 16$ \\
2 & $2.0 \pm 0.1$ & 1.9 & $0.3 \pm 0.03$ & $0.021 \pm 0.002$ & 0.41 & 88 & 6.2 & $226 \pm 16$ \\
3 & $2.4 \pm 0.1$ & 1.4 & $0.28 \pm 0.18$ & $0.016 \pm 0.004$ & 0.38 & 105 & 6.0 & $165 \pm 7$ \\
4 & $1.5 \pm 0.1$ & 1.6 & $0.09 \pm 0.01$ & $0.006 \pm 0.001$ & 0.37 & 21 & 1.4 & $35 \pm 24$ \\
5 & $>1.1$ & 1.2 & $0.06 \pm 0.01$ & $0.009 \pm 0.002$ & 0.38 & 10 & 1.5 & $24 \pm 12$ \\
\hline
\end{tabular}


on the Molenplaat (30 to $40 \%$ ) is consistent with estimates reported in Heip et al. (1995); however, data on tidal flats are too few to allow a proper comparison with other systems.

\section{Seasonal changes in sedimentation rates and silt content in relation to microphytobenthos and macrofauna}

${ }^{7} \mathrm{Be}$, with its short half-life of $53 \mathrm{~d}$, is more suitable for the study of short-term sedimentation. As Site 2 had the highest levels of radionuclides, it was used for the seasonal study of sediment dynamics of fine silt. Like ${ }^{210} \mathrm{~Pb}$ and ${ }^{137} \mathrm{Cs}_{1}{ }^{7} \mathrm{Be}$ is mainly associated with the fine particles rather than the sand fraction. Moreover, Olsen et al. (1986) observed that fine-particle deposition is the most important factor affecting the accumulation pattern and vertical distribution of ${ }^{7} \mathrm{Be}$ in estuarine systems.

${ }^{7} \mathrm{Be}$ was always detected in the top $6 \mathrm{~cm}$ of cores collected in June 1996, September 1996, March 1997, June 1997 and September 1997. The smooth decrease in its activities with depth suggests some bioturbational effect in the upper sediment (Fig. 3). However, there was a clear seasonal variation in activities, with values in-
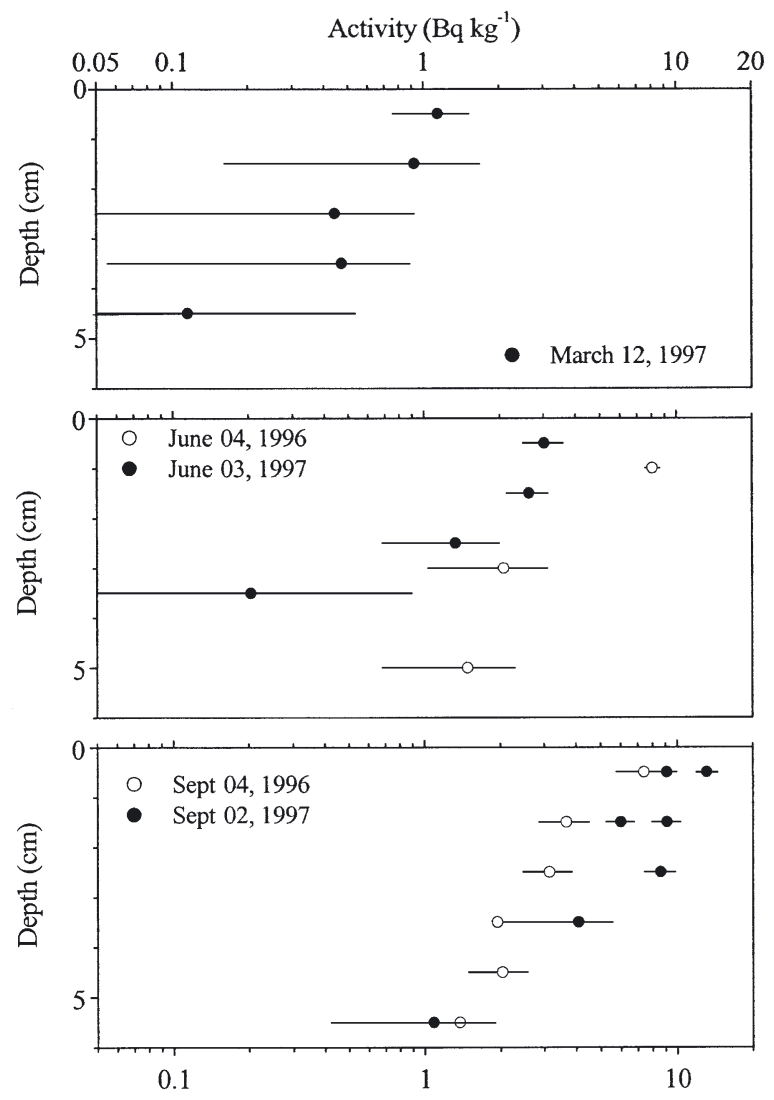

Fig. 3. Profiles of ${ }^{7}$ Be activity with sediment depth at Site 2 on Molenplaat tidal flat in March, June and September

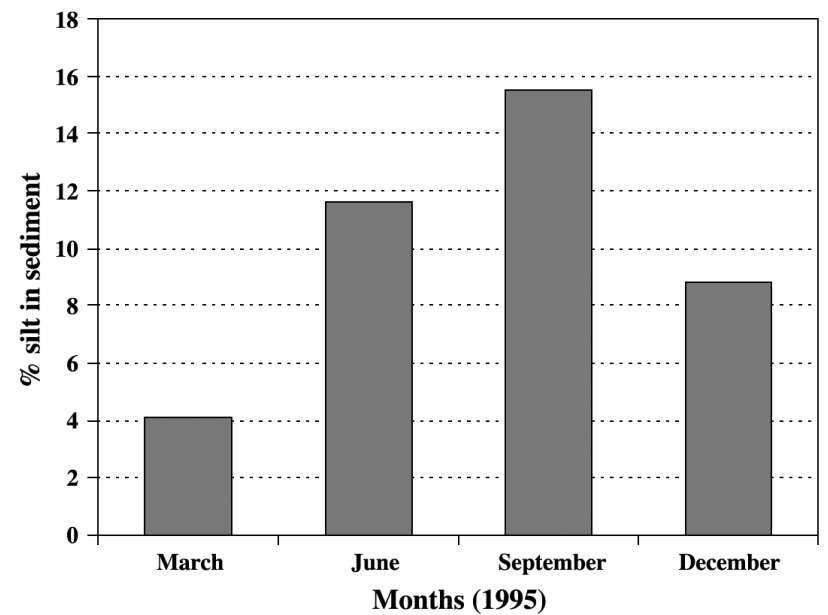

Fig. 4. Seasonal variation in silt content $(<50 \mu \mathrm{m})$ of sediment at Site 3 on the Molenplaat tidal flat in 1995

creasing from around $1 \mathrm{~Bq} \mathrm{~kg}{ }^{-1}$ in spring to $13 \mathrm{~Bq} \mathrm{~kg}^{-1}$ in late summer. Low ${ }^{7} \mathrm{Be}$ activities in March may indicate the disappearance of the finest fraction of the sediment (by erosion or drainage) during the winter. In contrast, the increase of ${ }^{7} \mathrm{Be}$ inventories in summer would indicate an increase in the content of fine particles in the sediment. Such a seasonal cycle in silt content of the sediment was observed on the Molenplaat tidal flat (Fig. 4, and Herman et al. 1999, 2001, Widdows et al. 2000a) and probably reflects the biodeposition by suspension-feeders (see later subsection 'Biodeposition').

Marked spatial and temporal differences in grain size distribution and sediment stability were observed on the Molenplaat (Table 1). Sandier sites at the edge of the tidal flat (Sites 4 and 5) had a low silt content ( 1\% silt) throughout the year, whereas the highest silt content occurred at the central sites (Sites 2 and 3). At the central sites, silt increased seasonally from $4 \%$ in March to $15.5 \%$ in September at Site 3 (Fig. 4) and to $28 \%$ in June and $38 \%$ in September at Site 2. Spatial and temporal changes (Table 1) in both physical factors (tidal currents, wind induced waves, bed roughness) and biological factors (suspension-feeding bivalves, enhanced sediment cohesion) are likely to contribute to the seasonal evolution of the silt content at these central sites.

The relationship between bottom shear stress and the abundance of sessile suspension feeders is predicted to be non-linear on sediment shores (Herman et al. 1999, Widdows et al. 2000a). In areas of high bed shear stresses with maximum near-bed current flows of 0.35 to $0.40 \mathrm{~m} \mathrm{~s}^{-1}$, sediment erosion and disturbance will limit infaunal suspension feeders such as Cerastoderma edule. At intermediate current velocities (e.g. 0.15 to $0.30 \mathrm{~m} \mathrm{~s}^{-1}$ ) there is greater sediment stability for the infauna and water exchange is sufficient to minimise near-bed seston depletion by suspensionfeeders, thereby sustaining a high biomass. In areas of 

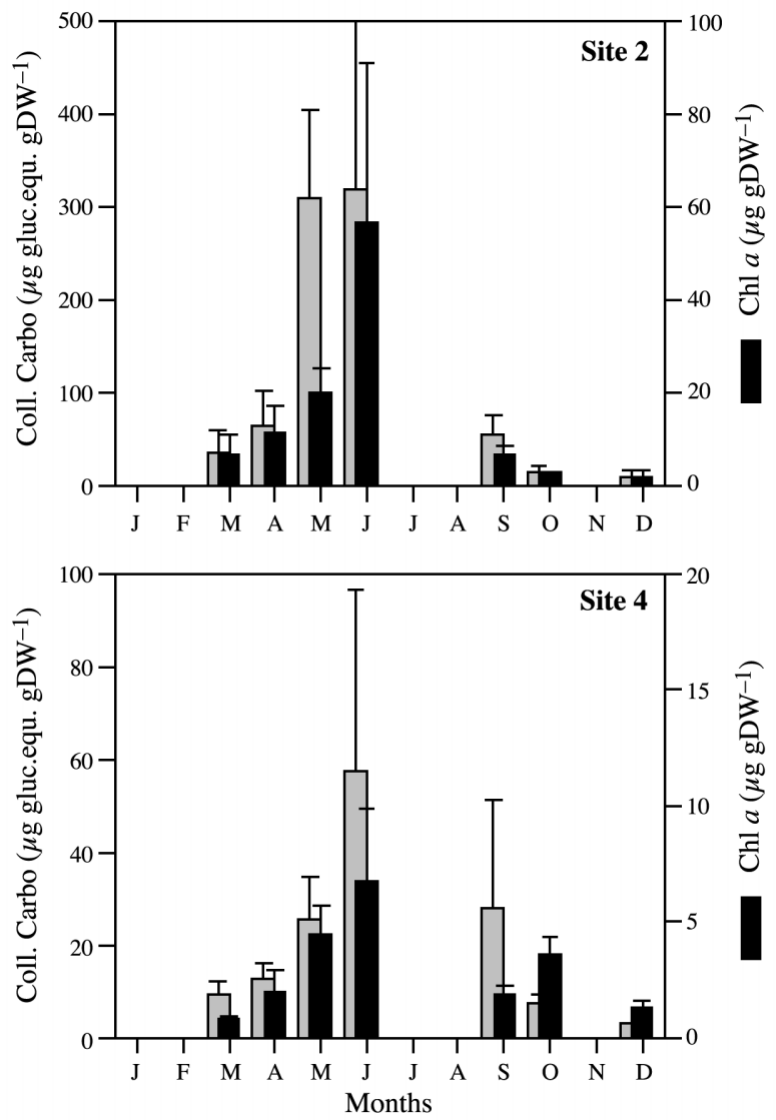

Fig. 5. Seasonal cycles in chlorophyll $a$ and colloidal carbohydrates at Site 2 (silty sediment) and Site 4 (sandy sediment) on Molenplaat tidal flat. (From Lucas et al. 2003)

low maximum current velocities (e.g. $<0.15 \mathrm{~m} \mathrm{~s}^{-1}$ ), seston depletion and food limitation will constrain the growth and biomass of suspension-feeders (Fréchette et al. 1989, Widdows et al. 2002). During the period from early spring to autumn there is a general increase in the biomass of the suspension-feeder C. edule (Herman et al. 1999) due to the summer growth period in established populations and the recruitment of newly settled individuals. In addition, there is a seasonal increase in the mass-specific filtration rate of $C$. edule (Newell \& Bayne 1980). This higher biomass and feeding rate will result in enhanced biodeposition of silt throughout the summer period, at a time of reduced wave activity and lower bed shear stresses. These processes account for the significant relationship between C. edule density and silt content $(\mathrm{r}=0.45 ; \mathrm{p}=0.01)$ on the Molenplaat. In contrast to silt content, seasonal changes in \% ash-free material in the sediment (reflecting particulate organic matter content) was less marked, with Site 2 showing the greatest change but only from 1.6 to $2.2 \%$ (Table 1 ). However, there was still a significant correlation between $C$. edule density and the particulate organic matter content of the sedi- ment $(\mathrm{r}=0.58 ; \mathrm{p}=0.001)$. Within this dynamic relationship there is potential for feedback mechanisms, via biodeposition, which will modify the properties of the sediment (e.g. increase silt and colloidal carbohydrate content) thus enhancing sediment cohesiveness and stability (see subsection 'Biodeposition'). These seasonal changes in macrofauna appear to be an important biological factor contributing towards the increase in silt content, reduction in the chlorophyll $a$ and the shift from stable to less stable sediments.

As with many tidal flats of NW Europe (Underwood \& Paterson 1993, de Jonge \& Colijn 1994, de Brouwer et al. 2000), the Molenplaat had a visible microalgal mat in the spring, composed primarily of benthic diatoms. Trends in the spatial distribution of microphytobenthos chlorophyll $a$ and colloidal carbohydrates reflected the spatial differences in physical properties of the sediment, with highest values (64 $\mu \mathrm{g} \mathrm{chl} \mathrm{a} \mathrm{g}{ }^{-1}$ dry mass, and $356 \mu \mathrm{g}$ glucose equiv. $\mathrm{g}^{-1}$ ) at the most stable and siltiest site (Site 2$)$ and lowest values $(0.8 \mu \mathrm{g}$ chl a $^{-1}, 5 \mu \mathrm{g}$ glucose equiv. $\mathrm{g}^{-1}$ ) at the most mobile and sandiest site (Site 5) (Table 1). Although peak values differed, both silty and sandy sediments displayed a clear seasonal cycle in microphytobenthos biomass and colloidal carbohydrate content, with peak values in June followed by a significant reduction by September (Fig. 5). There was a highly significant correlation between the chlorophyll $a$ and carbohydrate content of the surface sediments $(r=0.85 ; \mathrm{p}<0.0001)$. However, due to the marked seasonal changes in chlorophyll $a$ there was only a significant correlation between \% silt and chlorophyll $a$ when the spring and autumn data are considered separately $(r=0.79 ; \mathrm{p}<0.001$ and $\mathrm{r}=0.84 ; \mathrm{p}=0.001$, respectively).

\section{Spatial and temporal changes in sediment resuspension and deposition}

Flume studies recorded marked and significant spatial and temporal differences in sediment erodability (Table 1). There were no significant correlations between sediment erodability and the bulk physical properties of the top $1 \mathrm{~cm}$ of sediment (bulk density, \% water, $\%$ sand, \% POM). There was a significant negative relationship between sediment mass eroded and emersion time $(\mathrm{r}=-0.54 ; \mathrm{p}<0.005)$. The central sites, which were exposed for the longest period, were more stable (i.e. had the lowest erosion potential) than sites on the edge of the Molenplaat (Sites 1 and 4). Site 5, however, was an exception, with the longest emersion period $(7.5 \mathrm{~h})$ and relatively low sediment stability (i.e. mobile sand with ripples) (Table 1). All sites on the tidal flat were significantly more stable in June 1996 (i.e. higher $U_{\text {crit }}$ values ranging from 0.30 to $0.37 \mathrm{~m} \mathrm{~s}^{-1}$ ) compared to September 
$1996\left(U_{\text {crit }}\right.$ values of 0.14 to $\left.0.21 \mathrm{~m} \mathrm{~s}^{-1}\right)$. The high sediment stability in June 1996 was due to a combination of biotic factors, the biostabilisation of the sediment by benthic algal biofilms (microphytobenthos) and the relatively low biomass of the bioturbating clam Macoma balthica. Benthic algae produce extracellular polymeric substances (EPS, mainly colloidal carbohydrates), which increase the cohesiveness of the sediments, and this is reflected in the significant relationship between $U_{\text {crit }}$ (and mass eroded) and the chlorophyll a content of surface sediments $(\mathrm{r}=0.54 ; \mathrm{p}=0.005$ for 1996 and 1997 data). Field studies (Sutherland et al. 1998b, Austen et al. 1999, Paterson et al. 2000, Widdows et al. 2000a) have consistently demonstrated a significant correlation between sediment stability and the content of chlorophyll $a$ and EPS in the surface sediments. Furthermore, controlled laboratory flume experiments have confirmed that there is a cause-effect relationship between microphytobenthos chlorophyll a (and EPS) and sediment stability (Sutherland et al. 1998a). The mechanism of increased sediment stability through diatom biofilms is the production of EPS which form sticky coatings and enhance particle cohesiveness (Decho 2000).

The flume studies also showed the converse of bio-stabilisation, and highlighted a significant relationship $(r=0.775, p<0.005)$ between sediment erodability and the biomass of the surface deposit-feeding clam Macoma balthica (Widdows et al. 2000a). Over the $2 \mathrm{yr}$ (1996 and 1997), a significant relationship was only apparent for the siltier central sites (Sites 2 and $3 ; \mathrm{r}=0.59, \mathrm{p}<0.05$ ). These observations are consistent with other field studies in the Humber (Widdows et al. 1998a). Controlled laboratory studies have confirmed that sediment erodability increases with increasing $M$. balthica density (Widdows et al. 1998b). This species represents one of the key bioturbators on the tidal flat, and destabilises the sediment by its surface deposit-feeding. During the period from June 1996 through to September 1997, there was a significant decline in sediment stability at the central Molenplaat sites, which reflected the shift in the overall balance between the 'biostabilisers' (microphytobenthos) and the 'bio-destabilisers' (bivalves such as M. balthica and Cerastoderma edule). Reduced sediment stability in the autumn coincided with the breakdown of the microphytobenthos mat, due in part to the macrofauna grazing and increased bioturbation. In the autumn there were large amounts of phaeopigments relative to chlorophyll $a$ in the sediment, $>85 \%$ of which were phaeophorbides, a major by-product of metazoan grazing (Lucas \& Holligan 1999).

Field measurements at the 5 sites on the Molenplaat generally demonstrated a close coupling between current velocities and SPM during spring tides (Site 4 ; Fig. 6), with peaks in currents and SPM ca. $1.25 \mathrm{~h}$ before and after slack high water. There was also good agreement between the observed $U_{\text {crit }}$ (in the field, Fig. 7) and the predicted $U_{\text {crit }}$ (derived from flume experiments). This was particularly evident at sites on the edge of the tidal flat (Sites 1,4 and 5) where the resuspension/deposition processes involved fine sand grains that sank rapidly once the critical threshold for deposition was reached (Fig. 8, and Lucas et al. 2000). At the central sites, although the SPM peaks were associated with periods of high current velocity, the periods of benthic-pelagic flux were slightly less distinct due to a number of factors: (1) the greater sediment stability; (2) the advection of SPM from the peripheral areas of the tidal flat; and (3) the lower critical deposition threshold and settling velocities for the finer particles. 


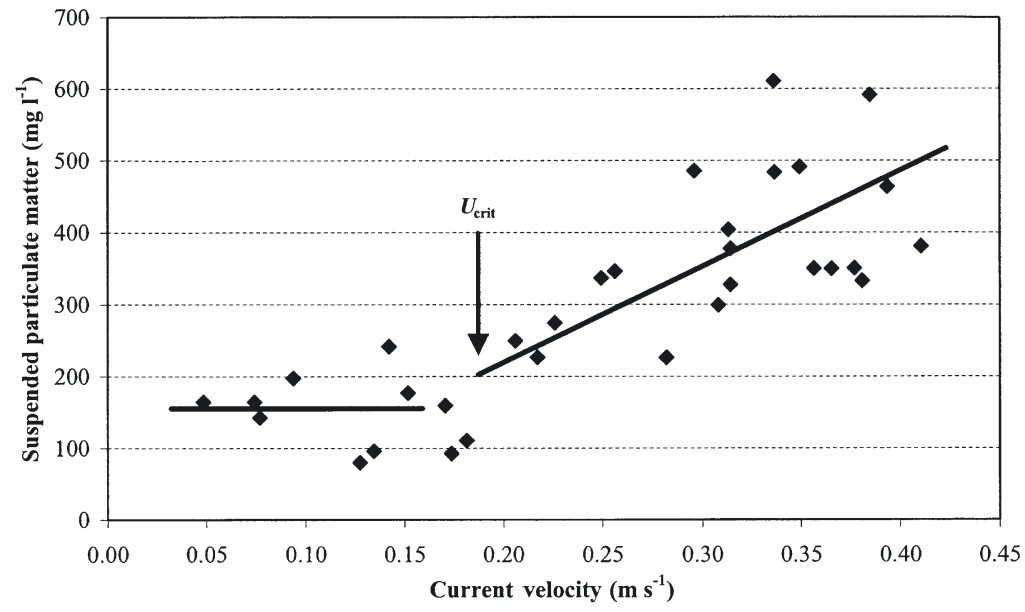

Fig. 7. Relationship between suspended particulate matter concentration and current velocity $(z=10 \mathrm{~cm}$ above seabed) at Site 4 on Molenplaat tidal flat in September 1997. Critical erosion threshold $\left(U_{\text {crit }}\right)$ of $0.19 \mathrm{~m} \mathrm{~s}^{-1}$ (field measure-ment) is in good agreement with annular flume studies (Table 1)
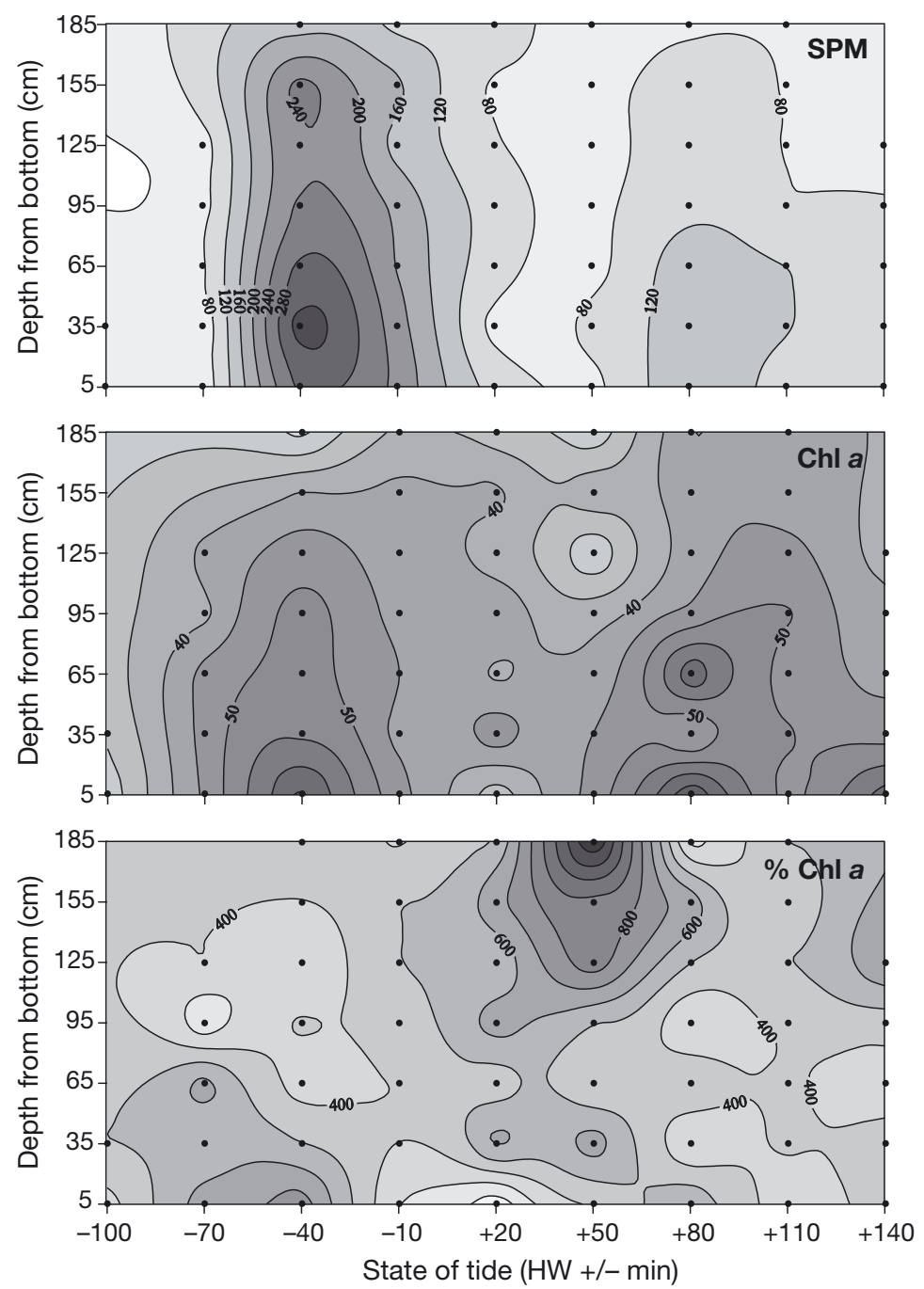

During the autumn and winter, silt content declined due to increased sediment erosion at this time of year. This is likely to be the result of interactions between physical and biological processes (including increased fluvial flows, storms and wave action) combined with reduced bio-stabilisation and increased bio-destabilisation of the sediment. The relative importance of these factors is unknown at present.

\section{Resuspension of microphytobenthos}

Microphytobenthos, because of their close association with sediments, are subjected to the same physical forces of tidal currents and wave energy that act to resuspend, transport and deposit sediment particles. Sampling of the water column for SPM, chlorophyll $a$, and diatom cell counts over a high-water period clearly identified resuspension and deposition events across the sediment-water interface occurring either side of the high-water slack period during a spring tidal cycle (Fig. 8, and Lucas et al. 2000). These field observations were consistent with the flume measurements of spatial and temporal differences in the erosion potential of sediment and microphytobenthos (Lucas et al. 2000, Widdows et al. 2000a). Peaks in chlorophyll $a$, its degradation products (phaeopigments) and SPM occurred in the water column above the bed, and were associated with resuspended benthic diatoms (primarily Navicula spp.) and large numbers of diatom frustules (Lucas et al. 2001). In addition, there was a major resuspension of some larger phytoplanktonic species, such as the centric diatom Coscinodiscus spp. ( 200 $\mu \mathrm{m})$, which sink to the bed at low current velocities (Lucas et al. 2001). At Site 4 (edge), the resuspension of both SPM and chlorophyll a was greater than at Site 2 (central) due to the lower stability of the underlying bed. Furthermore, there was greater vertical mixing (less stratification) with high chlorophyll $a$ values in the surface waters above Site 4 (Fig. 8).

Fig. 8. Water-column profiles of suspended particulate matter (SPM mg $\mathrm{l}^{-1}$ ) and chlorophyll a (mg $\mathrm{m}^{-3}$ ) over an immersion period at Site 4 on Molenplaat tidal flat (June 1996). HW: high water. (From Lucas et al. 2000) 
In numerical terms, benthic diatoms accounted for 15 to $42 \%$ of total diatom abundance in the water column over the flood-ebb period, while Coscinodiscus spp. accounted for 12 to $17 \%$ in June and $3 \%$ in late August. However, due to the larger cell size of the planktonic forms (e.g. Coscinodiscus spp.) compared to the benthic diatoms, the contribution of benthic diatoms to the total diatom carbon in the water column was $<1 \%$ in June, but up to $25 \%$ in late August (Lucas et al. 2001). The ecological consequences of these large differences in cell size and the resultant small contribution of benthic diatoms to the total diatom carbon in June have been clearly demonstrated in field studies using stable isotopes as trophic tracers (Herman et al. 2000). Despite the resuspension of benthic algae at high current velocities, suspension-feeders (such as Cerastoderma edule and Mya arenaria) had $\delta^{13} \mathrm{C}$ signatures close to that of pelagic algae, thus indicating that pelagic algae formed the major food source.

The quantity and quality of microphytobenthic resuspension on the Molenplaat tidal flat varied both spatially and temporally as a result of complex physical, chemical and biological interactions. Resuspension of benthic chlorophyll a was mainly related to the erosion behaviour (threshold and rate) of the sediment, including the stabilising influence of the microbial mat (Paterson \& Black 1999, Lucas et al. 2000) and the amount and vertical distribution of the microphytobenthos available for resuspension (Lucas \& Holligan 1999). Resuspension of the microphytobenthos is also influenced by the physical/biochemical properties of the sediment, as well as the presence and feeding activities of benthic deposit- and suspension-feeders. The temporal variation in microphytobenthic resuspension will occur (1) as a function of changes in current velocity during diurnal tidal cycles and the springneap cycle, (2) over seasonal cycles (due to variation in sediment stability, microphytobenthic growth and intermittent storms, and (3) in response to interannual variation (largely due to climatically driven changes in the biological cycles of benthic diatoms and grazers; Widdows et al. 2000b). The nature or quality of the resuspended benthic algae varied spatially, ranging from epipsammic diatoms attached to sand grains (Sites 4 and 5) to epipelic diatoms (such as the genera Navicula and Nitzschia) which tend to form dense algal mats on silty sediments (Sites 2 and 3) (Lucas et al. 2001).

\section{Flux of pigments into sediment}

Pigments in sediment can derive from 3 sources: (1) microphytobenthos produced in situ, (2) sedimentation of phytoplankton, and (3) macroalgal detritus.
HPLC and microscopic evidence demonstrated the presence of benthic and water-column-derived microalgal pigments in the surface layers of both silty and sandy sediments of the Molenplaat tidal flat, but there were pronounced differences in their biomass and vertical distribution (Lucas \& Holligan 1999). Sandier sediments were characterised by homogenous vertical profiles of chlorophyll $a$ in the upper $2 \mathrm{~cm}$ of sediment together with very low phaeopigments (degraded pigments) and the absence of water-column-derived pigments below the surface layer. This suggests that the greater sediment mobility and porosity of sandy sediments combined with the turbulence in the overlying water mixes and washes out fine particles, preventing accumulation of both autochthonous or allochthonous sources of microalgae.

In contrast, HPLC analysis of pigments in silty sediments provided evidence of a seasonal peak (in June) of microalgal biomass produced both in situ and in the water column. During the spring algal bloom period, high chlorophyll a levels at the surface decreased very rapidly with depth over the upper 5 to $10 \mathrm{~mm}$. This indicated that the degradation of algal pigments, through processes such as senescence, photodegradation, bacterial degradation and herbivore grazing, was more rapid than the vertical mixing (physical and biological) of cohesive/silty sediments (Sun et al. 1993, Lucas \& Holligan 1999). Large amounts of phaeopigments were produced in the Molenplaat sediment, with the relative contribution changing from phaeophytins in March/April to phaeophorbides in September as the role of the herbivorous community in chlorophyll a cycling became more significant. Bianchi et al. (1988) reported that phaeophorbides represented 40 to $60 \%$ of total phaeopigments in mesocosms with the deposit-feeders Macoma balthica and Leitoscoplos fragilis, but only 3 to $4 \%$ in controls without fauna. There was also evidence of inputs of pigments from water-column sources between June and September (Lucas \& Holligan 1999), indicated by the presence of peridinin (dinoflagellates) and 19'hexanoyloxyfucoxanthin (prymnesiophytes). During the late autumnwinter, the chlorophyll a content and pigment diversity decreased, coincident with reduced biological activity and increased physical mixing of the sediments. The ratio of fucoxanthin to chlorophyll $a$ is indicative of the microphytobenthos being dominated by diatoms in both sandy and silty sediments. By September, there was considerable accumulation of this material (high fucoxanthin:chlorophyll a ratios) down to several centimetres depth.

On tidal flats such as the Molenplaat, sandy sediments undergo rapid recycling of primary producers and there is no significant accumulation of pigments or organic material. At the silty sites, however, the bal- 
ance between import and export changes on a seasonal basis. During the spring and summer, these sites act as a sink for a part of the in situ production of benthic microalgae and for phytoplankton deposited from the water column. This carbon then becomes incorporated into the sediment and, as benthic macrofauna biomass increases during the summer and autumn, grazing acts to reduce the microalgal biomass. This also has the effect of reducing sediment stability, and then the sediment becomes more physically disturbed by currents and wave action with rapid recycling of material in the upper layers.

\section{Biodeposition}

The main suspension-feeder on the Molenplaat tidal flat was the cockle Cerastoderma edule. Experimental flume studies (Widdows et al. 2000a) showed a significant relationship between the suspension-feeding/ biodeposition rates and $C$. edule biomass $(r=0.91$, $\mathrm{p}<$ 0.001) and between sediment chlorophyll a/colloidal carbohydrate and $C$. edule biomass ( $\mathrm{r}=0.82 ; \mathrm{p}<0.05)$. Suspension-feeding activity of $C$. edule in September 1996 induced higher rates of biodeposition in the central region $\left(2.8\right.$ and $7.7 \mathrm{~g} \mathrm{~m}^{-2} \mathrm{~h}^{-1}$ at Sites 2 and 3, respectively), in contrast to zero biodeposition rates at the sandy edges of the Molenplaat (Sites 1 and 5; Widdows et al. 2000a). The occurrence of highest cockle densities and biomass in the central part of the Molenplaat can therefore play an active role in enhancing deposition rates, by at least 1 order of magnitude compared to sedimentation rates at sites without suspension-feeding bivalves (Widdows et al. 2000a). This is probably an important contributory factor to the increasing silt content of sediment during the spring-summer period.

A subsequent experiment examined this hypothesis and confirmed that Cerastoderma edule at a density of $350 \mathrm{~m}^{-2}$ not only increased the silt content 2.6-fold over a period of $7 \mathrm{~d}$ but also mixed the material into the sandy sediment to a depth of $3 \mathrm{~cm}$, by means of their burrowing/bioturbation activity. This vertical mixing and the rapid incorporation of surficial material at depth has also been confirmed by labelling experiments (see next subsection; Herman et al. 2000). While flume studies have shown that the majority of biodeposits will be resuspended during periods of maximum currents on flood and ebb tides, it only requires a small proportion of the biodeposits to be incorporated into the sediment during the slack-water period on each tidal cycle for the silt content to increase over the summer months. The fine silt then becomes resuspended, and is washed out of the muddy-sandy sediment during the winter storms.

\section{Mixing processes in sediment}

Sediment mixing is ultimately the result of numerous small-scale movements by benthic organisms and physical disturbances due to wave and current action. At the Molenplaat tidal flat, wave and current energy inputs to the sediment were highly variable in space and time. Similarly, sediment mixing due to organisms (i.e. bioturbation) was also highly variable because of the heterogeneity in the distribution, biomass and activity of the benthos.

Direct measurement of sediment mixing is extremely difficult and not yet feasible. However, the net result of sediment mixing can be studied using a variety of tracers, including radioactive and stable isotopes and chlorophyll a. In studies of the Molenplaat tidal flat, depth profiles of the natural radionuclides ${ }^{7} \mathrm{Be}$ and ${ }^{210} \mathrm{~Pb}$, chlorophyll $\mathrm{a}$ and ${ }^{13} \mathrm{C}$-labelled organic matter have been used (Schmidt et al. 1999, Middelburg et al. 2000). These different tracers integrate over different timescales, on the order of days for ${ }^{13} \mathrm{C}$-labelled organic matter, weeks for chlorophyll $a$, months for ${ }^{7} \mathrm{Be}\left(t_{1 / 2}=53.3 \mathrm{~d}\right)$, and years or decades for ${ }^{210} \mathrm{~Pb}\left(t_{1 / 2}=\right.$ $22.3 \mathrm{yr})$.

Sediment accumulation rates based on a variety of tracers revealed net sediment accretion rates on the

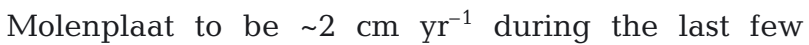
decades. If steady-state applies and there is no sediment mixing, then short-lived radionuclides would not be expected below $2 \mathrm{~cm}$. The measurements, however, showed significant excess activities at depths greater than $2 \mathrm{~cm}$. This implies either that seasonal varying sediment accumulation rates are considerably higher than the long-term net accumulation rate and/or that these radionuclides are transported to deeper layers by mixing processes. Assuming a constant delivery of these natural radionuclides and steady-state accumulation (Boudreau 1986), eddy-diffusion-type mixing coefficients ( $D_{\mathrm{b}}$ i Goldberg \& Koide 1962) for bulk sediment mixing were estimated to be 6 to $52 \mathrm{~cm}^{2} \mathrm{yr}^{-1}$ based on ${ }^{7} \mathrm{Be}$. Clifton et al. (1995) reported sediment mixing coefficients for intertidal sediments of the Tamar estuary of 1.8 to $108 \mathrm{~cm}^{2} \mathrm{yr}^{-1}$ based on ${ }^{7} \mathrm{Be}$, and of 8 to $43 \mathrm{~cm}^{2} \mathrm{yr}^{-1}$ based on ${ }^{210} \mathrm{~Pb}_{\text {; the }}$ the are consistent with our data. Moreover, Boudreau (1994) compiled sediment mixing coefficients, and reported those based on ${ }^{7} \mathrm{Be}$ in coastal sediments to vary between 3.8 and $9.1 \mathrm{~cm}^{2} \mathrm{yr}^{-1}$.

Chlorophyll a was observed down to $10 \mathrm{~cm}$ in the sediment, yet it is only delivered to the sediment surface by deposition of water-column algae and by microphytobenthos production in the top few millimetres. Assuming steady-state conditions, constant porosity, no compaction, negligible accumulation relative to mixing and a first-order degradation constant 
(k) of chlorophyll a of $10 \mathrm{yr}^{-1}$, the depth profile of chlorophyll a can be described (Sun et al. 1994) by:

$$
C=C_{0} \exp \left(\left[-k / D_{\mathrm{b}}\right]^{0.5} \mathrm{x}\right)
$$

where $C$ is the chlorophyll content, $C_{0}$ is the chlorophyll content in the surface layer, $D_{\mathrm{b}}$ is the sediment mixing coefficient and $x$ is depth in the sediment. Application of this model to our data yielded chlorophyll a-based mixing rates of 44 to $67 \mathrm{~cm}^{2} \mathrm{yr}^{-1}$, consistent with those based on ${ }^{7} \mathrm{Be}$ and literature estimates for coastal sediments (Boudreau 1994, Herman et al. 1999).

An in situ labelling study of microphytobenthos was carried out at 2 sites (Sites 2 and 4 ) on the Molenplaat to determine its fate (Herman et al. 2000, Middelburg et al. 2000). At the start of a tidal emersion period, ${ }^{13} \mathrm{C}$ bicarbonate was sprayed on the sediment surface, and the uptake of ${ }^{13} \mathrm{C}$ by the algae in the top $1 \mathrm{~mm}$ was linear during the whole period of light and aerial exposure (ca. $27 \mathrm{mg}^{13} \mathrm{C} \mathrm{m}^{-2} \mathrm{~h}^{-1}$ at both sites; Middelburg et al. 2000). Although the label incorporation per unit area were the same at Sites 2 and 4, the latter site showed a stronger specific labelling of organic matter, since the organic matter content and biomass of the algae were 8 to 10 times less in the top $1 \mathrm{~mm}$ of sediment. At the silty station (Site 2), about $75 \%$ of the label fixed by microphytobenthos was found in the top $1 \mathrm{~mm}$ after $4 \mathrm{~h}$, the remaining $25 \%$ being in deeper sediment layers (down to $15 \mathrm{~mm}$ ). About 35 to $40 \%$ of the label was found in the deeper layers after $1 \mathrm{~d}$ and about $60 \%$ from Day 2 onwards. At the sandy site (Site 4 ), about $40 \%$ of the label fixed was recovered in the top $1 \mathrm{~mm}$, the other $60 \%$ was found in the deeper sediment layers (down to $60 \mathrm{~mm}$ ). About $80 \%$ of the label was found in deeper layers after $1 \mathrm{~d}$. The residence time of microphytobenthos with respect to external losses (resuspension and respiration) was $\sim 2.4$ and $5.6 \mathrm{~d}$ at the sandy and silty sites, respectively. This rapid transfer of newly formed organic material from the surface of the sediment to deeper layers cannot be described using an eddy-diffusion type of approach, because the underlying concept, continuity in time and space, does not apply. This rapid transfer to deeper layers cannot be attributed to large-scale sediment movement, since the label would mainly be disappearing from the small area labelled rather than being mixed to deeper layers. Possible rapid transfer pathways include advective water flow drawing down microalgae at sandy sites, and rapid sediment mixing due to benthic organisms at silty sites (e.g. burrowing polychaetes down to $\sim 6$ to $8 \mathrm{~cm}$; the head-down deposit-feeder Heteromastus filiformis at 6 to $14 \mathrm{~cm}$; and burrowing bivalves including Cerastoderma edule at 2 to $3 \mathrm{~cm}$; Macoma balthica down to $\sim 8 \mathrm{~cm}_{i}$ and Mya arenaria down to $>10 \mathrm{~cm}$ ).

\section{Sediment transport modelling}

The model results adequately reproduced the time series and the spatial pattern of net sedimentation (Fig. 9). The area with net sedimentation was located at the central area of the Molenplaat tidal flat. Tidal variations of measured suspended particulates in the water column were reproduced, but somewhat smoothed, in the model. The net sedimentation flux in the model was $\sim 150 \mathrm{~g} \mathrm{~m}^{-2} 10 \mathrm{~d}^{-1}$, which is equivalent to $\sim 15 \mathrm{~g} \mathrm{~m}^{-2} \mathrm{~d}^{-1}$ for the central area of the tidal flat. Based on a dry density of $2650 \mathrm{~kg} \mathrm{~m}^{-3}$ and a wet density of $1700 \mathrm{~kg} \mathrm{~m}^{-3}$ (Widdows et al. 2000a), an estimated net sedimentation flux of $0.014 \mathrm{~mm} \mathrm{~d}^{-1}$ or $0.42 \mathrm{~mm} \mathrm{mo}^{-1}$ was calculated for June conditions. If the grain-size composition of the sediment ( $40 \%$ silt) is also taken into account, the total flux at the central site is increased to $1.05 \mathrm{~mm} \mathrm{mo}^{-1}$, or $1.26 \mathrm{~cm} \mathrm{yr}^{-1}$ ) assuming a constant accretion rate over the year. This compares with estimates, derived from depth profiles of radionuclides, ranging from $1.1 \mathrm{~cm} \mathrm{yr}^{-1}$ at the edge to $2.4 \mathrm{~cm}$ $\mathrm{yr}^{-1}$ at the centre of the tidal flat (Table 2).

A sensitivity analysis was performed to estimate the effect of several input items on the model output. In addition to certain process parameters (critical bottom shear stress for erosion, settling velocity), the availability of sediment in the model appeared to be an important factor determining the sedimentation flux. In particular, the suspended sediment concentration at the boundary downstream of the Molenplaat affects the sedimentation flux.

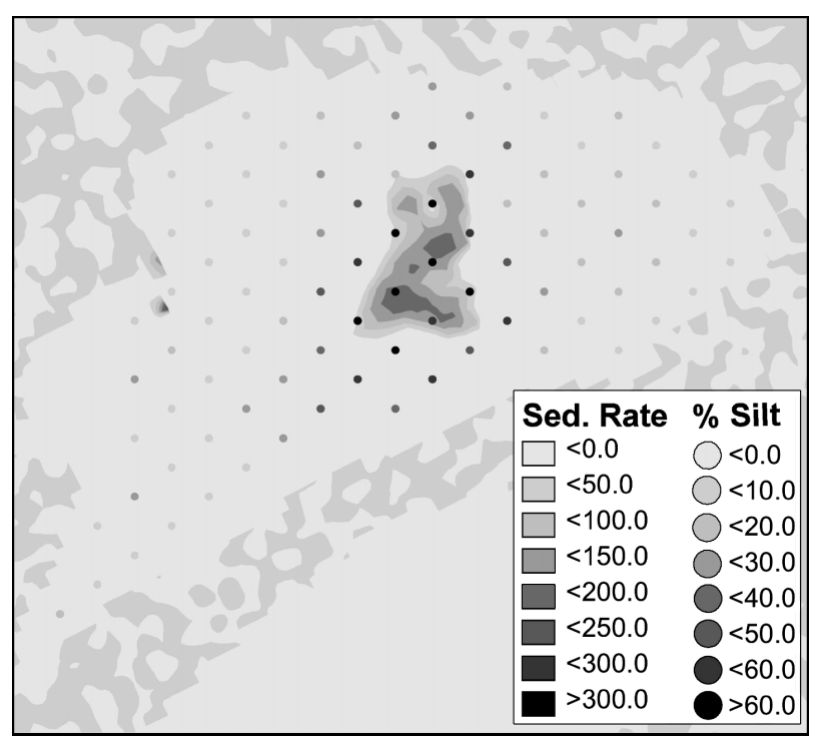

Fig. 9. Model output showing cumulative net sedimentation rate for Molenplaat tidal flat (without microphytobenthos) and $\%$ silt content. Key represents sedimentation rate of 0 to $>300 \mathrm{~g} \mathrm{~m}^{-2}$ over $10 \mathrm{~d}$, and \% silt content of 0 to $>60 \%$ 


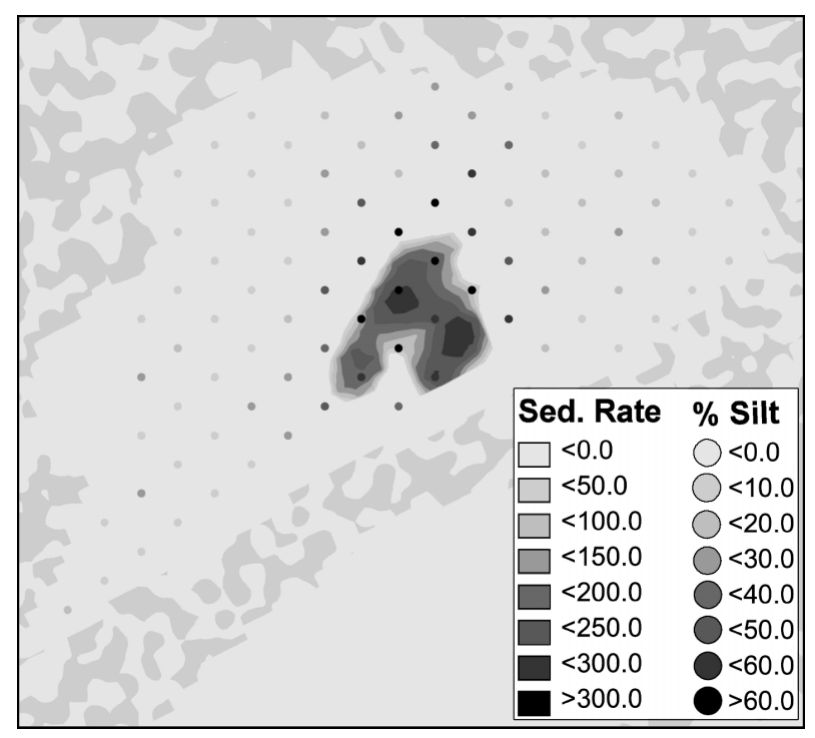

Fig. 10. Model output showing cumulative net sedimentation rate for Molenplaat tidal flat (with microphytobenthos increasing sediment stability at central sites) and \% silt content. Key represents sedimentation rate of 0 to $>300 \mathrm{~g} \mathrm{~m}^{-2}$ over $10 \mathrm{~d}$, and \% silt content of 0 to $>60 \%$

The model was also run to test the effect of increased sediment cohesiveness and stability as a result of algal biofilms. In the central part of the Molenplaat this resulted in an increase of the critical bed shear stress from ca. 0.3 to $0.45 \mathrm{~Pa}$. The results are presented in Fig. 10, which shows a 2 -fold increase in sedimentation rate in the central area $\left(30 \mathrm{~g} \mathrm{~m}^{-2} \mathrm{~d}^{-1}\right)$ and an increase in the silt content, which has moved south. Therefore, the addition of 1 important biological parameter, namely chlorophyll $a$, improves the model output in terms of both sedimentation rate and the location of the sediment with high silt content. As a result, the model output is in close agreement with field estimates of accretion rates derived from depth profiles of radionuclides.

The model output serves to demonstrate that the dynamics of fine silt cannot be modelled adequately by physical processes alone. However, the model can be significantly improved by the addition of a biotic factor (i.e. increase in sediment stability and critical bed shear stress due to microphytobenthos), thus supporting evidence from flume and field studies indicating that biological processes have a significant impact on sediment dynamics. Further improvements to the sediment dynamics model could include:

- additional biological processes recognised as important factors influencing sediment erosion and deposition (e.g. bioturbation and suspension-feeding); - improved representation of other grain sizes, since the dynamics of fine silt are not sufficient to describe the total net sedimentation of both fine silt and coarser particulates;
- better representation of reality, with details of tidal variations in SPM concentrations at the boundaries (ca. 20 to $150 \mathrm{mg} \mathrm{l}^{-1}$ ), seasonal variations in SPM concentrations at the boundaries (Herman et al. 2001), and the effects of wind and spring-neap cycles in tidal currents.

The model can be used to further investigate the relative importance of the different factors controlling sedimentation and erosion processes. For example, the effects of microphytobenthos mats and bioturbating clams on resuspension processes can be tested by creating spatial and temporal changes in Molenplaat sediment erodability in the model. Recently, other models of sediment dynamics have compared the relative importance of biological and physical processes on intertidal sediment transport (Willows et al. 1998, Wood \& Widdows 2002). These studies have demonstrated that bio-stabilisers (microphytobenthos), bioturbators (Macoma balthica), tidal range and offshore sediment supply all have an important impact on intertidal sediment erosion and deposition.

\section{Conclusions}

Total sediment accretion on the Molenplaat tidal flat was estimated to be $\sim 2 \mathrm{~cm} \mathrm{yr}^{-1}$, with total vertical mixing in the order of $50 \mathrm{~cm}^{2} \mathrm{yr}^{-1}$. Both physical and biological processes (i.e. tidal currents, bio-stabilisation, biodeposition and bioturbation) have been shown to influence sediment dynamics (erosion, transport, deposition and vertical mixing) on the tidal flat. Aspects of these different processes and their involvement in sediment dynamics have been quantified and discussed. A sediment transport model based on physical processes accounted for sedimentation rates of up to $1.26 \mathrm{~cm} \mathrm{yr}^{-1}$, which was $\sim 50 \%$ of the recorded rate in the central area. When sediment stability was increased due to the presence of microphytobenthos, the model output showed a 2-fold increase in sedimentation rate. However, a wider range of additional physical processes (tidal or seasonal variation in SPM, wind or effects of spring-neap tidal cycles) and biological processes (biodeposition from suspensionfeeding, bio-stabilisation and bioturbation) need to be incorporated into future models. In particular, spatial and temporal changes in the balance between 'biostabilisation' by microphytobenthos and 'bio-destabilisation' and grazers/bioturbators) on the tidal flats should be modelled. Further studies are required to improve the quantification of biological and physical processes, including their interactions, and to improve parameterisation of dynamic sediment models designed to incorporate biological processes as well as physical processes. 
Acknowledgements. This work is a contribution to the EU ELOISE Programme (ELOISE No. 461/23) in the framework of the ECOFLAT Project carried out under contract no. ENV4CT96-2016. This is contribution 3353 of the Netherlands Institute of Ecology (NIOO-KNAW).

\section{LITERATURE CITED}

Andersen TJ, Mikkelsen OA, Møller AL, Pejrup M (2000) Deposition and mixing depth on some European intertidal mudflats based on ${ }^{210} \mathrm{~Pb}$ and ${ }^{137} \mathrm{Cs}$ activities. Cont Shelf Res 20:1569-1591

Austen I, Andersen TJ, Edelvang K (1999) The influence of benthic diatoms and invertebrates on the erodibility of an intertidal mudflat, the Danish Wadden Sea. Estuar Coast Shelf Sci 49:99-111

Baptist M, Blauw A, Boon J, Marchand M, Thoolen P (1999) Modelling habitat characteristics in an estuary: hydrodynamic modelling, sediment transport modelling and upscaling in the Westerschelde estuary. Res Rep T1542/ Z2152. WL I Delft Hydraulics, Delft

Barlow RG, Mantoura RFC, Gough MA, Fileman TW (1993) Pigment signatures of the phytoplankton composition in the northeastern Atlantic during the 1990 spring bloom. Deep-Sea Res 40:459-477

Bianchi TS, Dawson R, Sawangwong P (1988) The effects of macrobenthic deposit-feeding on the degradation of chloropigments in sandy sediments. J Exp Mar Biol Ecol 122:243-255

Black KS (1999) Suspended sediment dynamics and bed erosion in the high shore mudflat region of the Humber estuary, UK. Mar Pollut Bull 37:122-133

Black KS, Paterson DM, Cramp A (1998) Sedimentary processes in the intertidal zone. Spec Publ Geol Soc Lond 139

Boudreau BP (1986) Mathematics of tracer mixing in sediments. 2. Non-local mixing and biological conveyor-belt phenomena. Am J Sci 286:199-238

Boudreau BP (1994) Is burial velocity a master parameter for bioturbation? Geochim Cosmochim Acta 58:1243-1249

Callaway JC, DeLaune RD, Patrick WH Jr (1996) Chernobyl ${ }^{137} \mathrm{Cs}$ used to determine sediment accretion rates at selected northern European coastal wetlands. Limnol Oceanogr 41:444-450

Clifton RJ, Watson PG, Davey JT, Frickers PE (1995) A study of processes affecting the uptake of contaminants by intertidal sediments, using the radioactive tracers: ${ }^{7} \mathrm{Be},{ }^{137} \mathrm{Cs}$ and unsupported ${ }^{210} \mathrm{~Pb}$. Estuar Coast Shelf Sci 41:459-474

Cundy AB, Croudace IW (1995) Sedimentary and geochemical variations in a salt marsh/mud flat environment from the mesotidal Hamble estuary, southern England. Mar Chem 51:115-132

Daborn GR (1991) Littoral investigation of sediment properties, Minas Basin, 1989. Final Report, Acadia Centre for Estuarine Research, Acadia University, Wolfville, NS. ACER Publ 17

de Brouwer JFC, Bjelic S, de Deckere EMGT, Stal LJ (2000) Interplay between biology and sedimentology in a mudflat (Biezelinge Ham, Westerschelde, The Netherlands). Cont Shelf Res 20:1159-1177

Decho AW (2000) Microbial biofilms in intertidal systems: an overview. Cont Shelf Res 20:1257-1273

de Jonge VN, Colijn F (1994) Dynamics of microphytobenthos biomass in the Ems estuary. Mar Ecol Prog Ser 104: 185-196

Dyer KR (2000) Intertidal mudflats: properties and processes. Special Issue. Cont Shelf Res (Spec Iss) 20
Fréchette M, Butman CA, Geyer WR (1989) The importance of boundary-layer flows in supplying phytoplankton to the benthic suspension feeder, Mytilus edulis L. Limnol Oceanogr 34:19-36

Goldberg ED, Koide M (1962) Geochronological studies of deep-sea sediments by the Io/Th method. Geochim Cosmochim Acta 26:417-450

Heip CHR, Goosen NK, Herman PMJ, Kromkamp J, Middelburg JJ, Soetaert K (1995) Production and consumption of biological particles in temperate tidal estuaries. Oceanogr Mar Biol Annu Rev 33:1-150

Herman PMJ, Middelburg JJ, Van de Koppel J, Heip CHR (1999) Ecology of estuarine macrobenthos. Adv Ecol Res 29:195-240

Herman PMJ, Middelburg JJ, Widdows J, Lucas CH, Heip CHR (2000) Stable isotopes as tropic tracers: combining field sampling and manipulative labelling of food resources for macrobenthos. Mar Ecol Prog Ser 204:79-92

Herman PMJ, Middelburg JJ, Heip CHR (2001) Benthic community structure and sediment processes on an intertidal flat: results from the ECOFLAT project. Cont Shelf Res 21: 2055-2071

Krone RB (1962) Flume studies of the transport of sediment in estuarial shoaling processes. Report. University of California, Hydraulic Engineering and Sanitary Engineering Laboratory, Berkeley, CA

Lucas CH, Holligan PM (1999) Nature and ecological implications of algal pigments diversity on the Molenplaat tidal flat (Westerschelde estuary). Mar Ecol Prog Ser 180:51-64

Lucas CH, Widdows J, Brinsley MD, Salkeld PN, Herman PMJ (2000) Benthic-pelagic exchange of microalgae at a tidal flat. 1. Pigment analysis. Mar Ecol Prog Ser 196:59-73

Lucas CH, Banham C, Holligan PM (2001) Benthic-pelagic exchange of microalgae at a tidal flat. 2. Taxonomic analysis. Mar Ecol Prog Ser 212:39-52

Lucas CH, Widdows J, Wall L (2003) Relating spatial and temporal variability in sediment chlorophyll $a$ and carbohydrate distribution with erodability of a tidal flat. Estuaries 26:885-893

Middelburg JJ, Klaver G, Nieuwenhuize J, Wielemaker A, de Haas W, Vlug T, van der Nat JFWA (1996) Organic matter mineralization in intertidal sediments along an estuarine gradient. Mar Ecol Prog Ser 132:157-168

Middelburg JJ, Barranguet C, Boschker HTS, Herman PMJ, Moens T, Heip CHR (2000) The fate of intertidal microphytobenthos: an in situ ${ }^{13} \mathrm{C}$ labelling study. Limnol Oceanogr 45:1224-1234

Newell RIE, Bayne BL (1980) Seasonal changes in the physiology, reproductive condition and carbohydrate content of the cockle Cardium (= Cerastoderma) edule (Bivalvia: Cardiidae). Mar Biol 56:11-19

Nieuwenhuize J, Maas YEM, Middelburg JJ (1994) Rapid analysis of organic carbon and nitrogen in particulate materials. Mar Chem 45:217-224

Olsen CR, Larsen IL, Lowry PD, Cutshall NH, Nichols MM (1986) Geochemistry and deposition of ${ }^{7} \mathrm{Be}$ in riverestuarine and coastal waters. J Geophys Res 91:896-908

Partheniades E (1962) A study of erosion and deposition of cohesive soils in salt water. $\mathrm{PhD}$ thesis, University of California, Berkeley

Paterson DM, Black KS (1999) Water flow, sediment dynamics and benthic biology. Adv Ecol Res 29:155-193

Paterson DM, Tolhurst TJ, Kelly JA, Honeywill C and 6 others (2000) Variations in sediment properties, Skeffling mudflat, Humber Estuary, UK. Cont Shelf Res 20:1371-1396

Schmidt S, Reyss JL, Herman PMJ (1999) Sedimentation patterns of a tidal flat in the Westerschelde estuary. In: 
Kraus NC, McDougal WG (eds) Proc 4th Int Symp Coastal Engineering and Science of Coastal Sediment Processes, Vol 3. ACSE, Reston, VA, p 1927-1935

St-Onge G, Hillaire-Marcel C (2001) Isotopic constraints of sedimentary inputs and organic carbon burial rates in the Saguenay Fjord, Quebec. Mar Geol 176:1-22

Sun MY, Lee C, Aller RC (1993) Anoxic and oxic degradation of ${ }^{14} \mathrm{C}$-labelled chloropigments and a ${ }^{14} \mathrm{C}$-labelled diatom in Long Island Sound sediments. Limnol Oceanogr 38: 1438-1451

Sun MY, Aller RC, Lee C (1994) Spatial and temporal distributions of sedimentary chloropigments as indicators of benthic processes in Long Island Sound. J Mar Res 52:149-176

Sutherland TF, Amos CL, Grant J (1998a) The effect of buoyant biofilms on the erodability of sublittoral sediment of a temperate microtidal estuary. Limnol Oceanogr 43: 225-235

Sutherland TF, Grant J, Amos CL (1998b) The effect of carbohydrate production by the diatom Nitzschia curvilineata on the erodability of sediment. Limnol Oceanogr 43:65-72

Underwood GJC, Paterson DM (1993) Seasonal changes in diatom biomass, sediment stability and biogenic stabilization in the Severn estuary. J Mar Biol Assoc UK 73:871-887

Underwood GJC, Paterson DM, Parkes RJ (1995) The measurement of microbial carbohydrate exoploymers from intertidal sediments. Limnol Oceangr 40:1243-1253

Widdows J, Brinsley MD, Elliott M (1998a) Use of in situ flume

Editorial responsibility: Otto Kinne (Editor),

Oldendorf/Luhe, Germany to quantify particle flux (deposition rates and sediment erosion) for an intertidal mudflat in relation to changes in current velocity and benthic macrofauna. Spec Publ Geol Soc Lond 139:85-97

Widdows J, Brinsley MD, Salkeld PN, Elliott M (1998b) Use of annular flumes to determine the influence of current velocity and biota on material flux at the sediment-water interface. Estuaries 21:552-559

Widdows J, Brinsley MD, Salkeld PN, Lucas CH (2000a) Influence of biota on spatial and temporal variation in sediment erodability and material flux on a tidal flat (Westerschelde, The Netherlands). Mar Ecol Prog Ser 194:23-37

Widdows J, Brown S, Brinsley MD, Salkeld PN, Elliott M (2000b) Temporal changes in intertidal sediment erodability: influence of biological and climatic factors. Contin Shelf Res 20:1275-1289

Widdows J, Lucas JS, Barrett C, Brinsley MD, Salkeld PN, Staff FJ (2002) Investigation of the effects of current velocity on mussel feeding and mussel bed stability using an annular flume. Helgol Meeresunters 56:3-12

Willows RI, Widdows J, Wood RG (1998) Influence of an infaunal bivalve on the erosion of an intertidal cohesive sediment: a flume and modelling study. Limnol Oceanogr 43:1332-1343

Wood RG, Widdows J (2002) A model of sediment transport over an intertidal transect, comparing biological and physical factors. Limnol Oceanogr 47:848-855

Submitted: June 4, 2003; Accepted: March 11, 2004

Proofs received from author(s): June 1, 2004 